\title{
Resolutions: Conviction, Absolution, and Mitigation
}

The resolution of criminal trials took many forms, from peace agreements, to absolutions, to public executions. Criminal trials at Reggio are characterized by a high overall conviction rate, which was approximately 90 percent in the period under examination; of these convictions, 48.5 percent were ordered in absentia. Overall, only a little more than five percent of cases saw the defendants absolved from charges. The other four and a half percent ended in a variety of ways: with orders from Milan to stop proceedings, with cases cancelled without surviving explanation, or with gratia granted by the Visconti. When convictions in absentia are not considered, we find that 86.5 percent of trials ended in conviction. ${ }^{1}$

These conviction rates suggest an important distinction between those periods in which accusation was the dominant procedure and those in which inquisition was the regular trial procedure. At Perugia in the thirteenth century, very high rates of acquittal-between 80 percent and 90 percent-reflected the realities of accusatorial procedure, in which parties frequently withdrew their complaints before sentencing. ${ }^{2}$ For a fee, the complainant in an accusatio could withdraw the charge at any moment before the reading of the verdict, thus avoiding sentencing. This made accusatorial procedure a useful tool in private conflicts and disputes, because the complainants could inconvenience and humiliate their opponents publicly in court and air their grievances, and even force the construction of a peace agreement, without losing control of the process.

However, the type of trial procedure used did not necessarily predict conviction rates: Sarah Blanshei's study of late thirteenth century Bologna found high acquittal rates in inquisition trials. In her sample, acquittals and suspensions of trials accounted for 35 percent of trials from $1285^{-1296}$, and in the early fourteenth century those numbers were even higher: 46.6 percent for

\footnotetext{
1 Of a sample of 357 cases where the defendants appeared in court (regardless of plea) and where the notary recorded the outcome of the trial.

2 Vallerani, "Procedure and Justice," 33.

(C) Joanna Carraway Vitiello, 2016 | DOI 10.1163/9789004311350_007

This is an open access title distributed under the terms of the Creative Commons AttributionNoncommercial-NonDerivative 3.o Unported (CC-BY-NC-ND 3.0) License, which permits any noncommercial use, and distribution, provided no alterations are made and the original author(s)
} 
1304-1326. ${ }^{3}$ These numbers also include trial suspensions; if those are removed, then evidence from inquisition trials in Bologna reflects a 28.8 percent acquittal rate. ${ }^{4}$ Conviction rates also vary significantly. Early fourteenth century Bologna saw 45.3 percent of trials ending in conviction, including bans for contumacy. In early fifteenth century Florence, Laura Stern found that conviction rates for ex officio trials (46.4 percent) were lower than those for trials that originated in public fame denunications (8o percent)..$^{5}$ Other courts that operated primarily with inquisitio have acquittal and conviction rates similar to that of late fourteenth-century Reggio. In mid-fifteenth century Mantua, assault constituted the most frequent crime, and the absolution rate from that charge was 11 percent, while approximately 41 percent of defendants charged were contumacious and 48 percent were convicted. ${ }^{6}$

While these comparisons offer useful perspective, they span a great deal of time-approximately 150 years - and involve cities with vast political differences. High conviction rates were shaped by a number of factors, some of which were localized. Confessions were desirable because they allowed the judge to convict with irrefutable full proof, which was obviously far preferable to deciding a case based on circumstantial evidence, and they could be encouraged in different ways. Torture, which was implemented with different criteria in different times and places, surely played a role in influencing confession and conviction rates, though the nature of the surviving evidence makes it difficult to define exactly what that role was. At Reggio, as in many other Italian cities, confessions were also encouraged with a one-quarter mitigation of pecuniary penalties if the defendants confessed. For crimes that did not carry a capital penalty, confession could be part of a defense strategy to lower fines and limit the damage of conviction. Modern criminal justice systems like that of the United States have similarly high conviction rates when the defendants go to trial, and also rely heavily on confession, even to the point of negotiating with defendants to obtain them. But medieval mitigation was not equivalent to modern plea bargaining: the medieval court did not negotiate with defendants to elicit a guilty plea, and the amount of the mitigation was set by statute.

3 Blanshei, Politics and Justice, 338.

4 Blanshei, Politics and Justice, 598, Table v.2.

5 Stern, Criminal Law System, 204, Table 2 and 204-208.

6 Trevor Dean and David Chambers, Clean Hands and Rough Justice:An Investigating Magistrate in Renaissance Italy (Ann Arbor: University of Michigan Press, 1997), 66-67, Table 1. These statistics were calculated from the numbers provided in "Table 1: Sentences in the Mantuan Podestà's Court, 1448-63." 
Still, confession provided one of the few moments in the inquisitorial trial at Reggio where the defendant could shape the sentence.

\section{The Weighing of the Evidence: Statutory Proofs vs. Judicial Discretion}

We do not know how or why the judges at Reggio Emilia reached their verdicts, and there is no scholarly consensus on the nature of judicial discretion in the late medieval court. Judges left no justifications or explanations of their verdicts. Indeed, jurists like Hostiensis, Durantis, Baldus, and Johannes Andreae actively discouraged them from doing so in order to avoid appeals, because erroneous legal reasoning could nullify an entire process. ${ }^{7}$ John Langbein argued that the medieval judge had little if any discretion by virtue of the theoretical basis of the judge's authority: when the earlier Germanic system of "non-rational" proofs was abolished at the Fourth Lateran Council, and inquisition replaced trials by ordeal, the judge's decision replaced the judgment of God. The system of statutory proofs was the answer to this dilemma. By disallowing judicial discretion, the determination of guilt or innocence was determined by an objective standard, difficult to meet and applicable to everyone. ${ }^{8}$

But in practice, this could present problems, and a judge might be persuaded of guilt or innocence even though the proof did not technically meet the standards. Thirteenth-century jurists took up this question. What if, asked Thomas de Piperata, a judge knows a man is innocent, but the evidence is enough to prove him guilty? Can the judge absolve him? Jacques de Révigny, professor of law in Orléans, perhaps echoed a dominant view when he insisted that the judge must base his decision on the proof, arguing that the judge is sworn to obey the law, and he must uphold that oath. After all, he observed, "if the judge could judge according to conscience, he would always feign conscience, whereas conscience should not be feigned." Even without this blatant

7 Julius Kirshner, "Consilia as Authority in Late Medieval Italy" in Legal Consulting in the Civil Law Tradition, eds. Mario Ascheri, Ingrid Baumgärtner and Julius Kirshner. Studies in Comparative Legal History. (Berkley: University of California Press, 1999), 125. At Reggio Emilia, no appeal was possible from a criminal process. The defendant's only recourse lay either in requesting clemency from Milan or perhaps in making a complaint at the time of the judge's syndication.

8 Langbein, Torture and the Law of Proof, 6-8.

9 "Si iudex posset iudicare secundum conscientiam, semper fingeret conscientiam ubi conscientia non esset fingenda," quoted in Padoa-Schioppa, Italia ed Europa nella storia del diritto, $272-273$. 
distrust, another weighty issue hung in the balance: if the judge decides a case based on personal knowledge that was not introduced as evidence, has he not become a witness in the very case that he is called upon to decide? A longstanding maxim of Roman law held that a judge cannot be a party to a case. Jurists like Bartolus and Baldus were very clear on this point. ${ }^{10}$

Yet the evaluation of circumstantial evidence called upon the judge to make decisions about its reliability, and there was substantial debate among jurists convictions based on indicia. Gandinus argued that a judge could convict on the basis of undoubted circumstantial evidence. ${ }^{11}$ The issue was one of conscience, which traditionally meant the judge's awareness of facts pertinent to the trial but not in evidence. However Gandinus assimiliated this, "in a manner more or less surreptitious," with the discretionary power of the judge. This allowed the judge to consider the defendant's fama, and also to examine his aspect using his own observation, not relying upon evidence that had been introduced. For Gandinus, the "conscience" of the judge signified his ability and perhaps his duty to choose which evidence is significant and to evaluate the defendant's person through his own observation. ${ }^{12}$ Vallerani observed that Gandinus's definition of conscience merges the concept together with statutory arbitrium. ${ }^{13}$ Bartolus traced the judge's decision to convict through stages of belief: from not knowing (nescientia), to forming doubt (dubitatio), to developing a suspicion (suspicatio), and then, considering the arguments before him, forming an opinion (opinio); finally, the judge is fully persuaded, and his belief (credas) in guilt or innocence is established. ${ }^{14}$

Once again, in practice, it proves difficult to make broad generalizations. Judicial discretion, or arbitrium, had a range of interpretations. In Venice, which operated outside the norms of the ius commune, arbitrium in this sense

10 Padoa-Schioppa, Italia ed Europa nella storia del diritto, 275-277. There were dissenters from this view. John Wycliff would object to this stance on the grounds that a judge should not violate divine law by rendering a sentence he knows to be unjust. It would be better, he said, for the judge to recuse himself and stand as witness in the case before another judge. But this was not the common opinion.

Fraher, "Conviction according to Conscience," 41-43. Fraher examined this debate on judicial discretion from the time of Lateran IV in 1215 to the publication of Durantis's Speculum iudiciale around 1270, focusing particularly on the treatise of Thomas de Piperata, whose Tractatus de fama was a source for Gandinus's Tractatus de maleficiis.

12 Vallerani, "Procedure and Justice," 55.

13 Vallerani, "Procedure and Justice," $52-57$.

14 “...tunc dicitur perfecta credulitas seu perfecta probatio, nec est tunc causa dubia ... Nam prout dicit credas, loquitur de plena fide et plena probatione, qua ad perfectam credulitatem adducitur iudex." Quoted in Lévy, La hiérarchie des preuves, 28. 
of decisions made by the judge's own conscience was a fundamental component of the justice system. Indeed the Venetian interpretation of discretion was so broad as to allow judges to consider acts as crimes that had never before been declared criminal..$^{15}$ An open allowance of conviction based upon conscience, however, had inherent dangers and required deep trust in the magistrates. Florence, which (like most Italian cities) operated in the world of the ius commune, allowed discretion in a more limited way. Discretion in Florence meant that the judge could use extraordinary measures, including evaluation of circumstantial evidence or torture, to inform his decisions, but " $\mathrm{t}]$ he closest Florentine judges got to possessing the power of discretion as conscience was their power to use analogy and precedent."16 Arbitrium in conviction was certainly not fully conceded in Reggio's statutes, which required judges to consider all the proofs available to them. Only in a few instances did Reggio's statutes mandate particular thresholds of proof necessary for a conviction, though given the legal education of the judges at Reggio, we can imagine they were well familiar with the concepts. And as we have seen, judges occasionally seemed moved to convict in cases where the evidence presented would not meet the standards of full proof. ${ }^{17}$

\section{Contumacy, Conviction in absentia, and the Criminal Ban}

Almost half the cited defendants failed to appear to answer charges. The contumacy rate at Reggio averaged approximately forty eight percent at the end of the fourteenth century. ${ }^{18}$ Reggio was not unusual in this respect: trial registers from the court of the Podestà at Bologna also yield high numbers in the late fourteenth century, fifty two percent in 1372 , and forty four percent in $1393 \cdot{ }^{19}$

15 Stern, "Politics and Law in Renaissance Florence and Venice," 219. Stern observed that the growth of discretion in the Venetian system increased together with aristocratic domination of the government.

16 Stern, "Politics and Law in Renaissance Florence and Venice," 215-216.

17 As in the case of Antonius de Albrixiis, discussed above in Chapter Four, ASRe, Giudiziario, Libri delle denunzie, April 28, 1403, vol. 20, fols. 1-3v.

18 On contumacy at Reggio Emilia and the problem of conviction in absentia, see Joanna Carraway, "Contumacy, Defense Strategy, and Criminal Law in Late Medieval Italy." Law and History Review 29.1 (February 2011): 99-132.

19 These statistics are calculated from the surviving trials in AsB, Curia del Podestà, Giudici ad maleficia, Libri inquisitionum et testium, b.214, 1372 and b.264, 1393. The 1372 sample is of 88 defendants, while the 1393 sample includes outcomes for 70 defendants. 
Florence in the 1380 's had a contumacy rate of fifty six percent, ${ }^{20}$ and the fifteenth century saw contumacy rates averaging between two-thirds and three-fourths of recorded cases, with four-fifths in $145^{6.21}$

The widespread nature of the problem with contumacy underlines the limited reach of the podesterial court, both in the urban sphere and in the contado. In Siena, population growth that outstripped available policing resources aggravated the high rates of contumacy, ${ }^{22}$ while stronger policing in Florence in the early fifteenth century led to a drop in contumacy rates. ${ }^{23}$ Population growth was obviously not a primary issue at Reggio Emilia, but the limited policing resources combined with strong pools of autonomy in the contado certainly contributed to the problem.

Recent scholarship has suggested that contumacy and its legal remedy, the criminal ban, served dispute resolution by allowing a "cooling off" period between affected parties, and thus perhaps limiting the vendetta. In this view, contumacy could even be desirable from the court's perspective, allowing judges to avoid rendering verdicts in contentious or politically volatile cases. ${ }^{24}$ Certainly contumacy could play a role inside a larger defense strategy, but medieval jurists did not see the problem this way. Contumacy did not serve the "public interest," which was the focus of the criminal law. Therefore it needed a remedy.

The solution was conviction in absentia by holding contumacy equivalent to a confession. Legally and technically this was problematic, because there was no formal judgment (res iudicata). Should defendants be convicted if they had no opportunity to present a defense, and no trial? Though it did conflict with Roman law interpretations, the response in municipal statutes tended to be affirmative, and conviction in absentia had become common practice at the end of the fourteenth century. The accused was to be convicted "just as though he confessed and was convicted of the crime for which he was blamed."25

20 Stern, Criminal Law System, 229.

21 Dean and Chambers, Clean Hands and Rough Justice, 65.

22 Pazzaglini, The Criminal Ban of the Sienese Commune, 3-4.

23 Stern, Criminal Law System, 229. Stern found contumacy rates of 58.3 percent from $135^{2-} 55$, and 55.6 percent from $1380-83$. However the numbers in the early fifteenth century were lower: a sample from $1425^{-28}$ shows a reduction to 42.4 percent, which Stern attributed in part to a more effective criminal justice system and a more effective police force Stern, Criminal Law System, 210).

24 Daniel Lord Smail, The Consumption of Justice: Emotions, Publicity, and Legal Culture in Marseille, 1264-1423 (Ithaca: Cornell University Press, 2003), 116.

25 BSR, Statuti, ms. 77, fol. 52r: "... tamquam confessus et convictus de delicto de quo inculpatur." 
The statutes of Reggio Emilia allowed it, ${ }^{26}$ as did statutes from Ravenna, ${ }^{27}$ Florence, ${ }^{28}$ and Bologna, ${ }^{29}$ to name only a few. Most contumacious felons were then placed under a bannum pro maleficio, a criminal ban.

The proclamation of the criminal ban served as an assertion of jurisdiction, and it took place in several stages. Immediately after the defendant's failure to appear, a bannum simplex warned the accused to appear before the judge within a certain number of days. If the defendant persisted in contumacy, the bannum conditionale was issued, which effectively placed the accused under ban unless he or she appeared before the judge. The proclamation of the bannum conditionale set forth the terms of the ban, including the amount of the ban, whether the defendant's goods were to be confiscated, and whether the ban was in persona, meaning the defendant's person could be assaulted with impunity. A term was given within which the defendant could appear before the judge and avoid the consequences of the ban (but not the penalty of the crime). The final step took place when the bannum conditionale expired..$^{30}$ The ban had to be entered into the Libri bannitorum to be considered valid. ${ }^{31}$ Those banned for major felonies were set beyond the protection of the law.

Banniti pro maleficia were often able to live outside the reach of the law, finding shelter in the contado or escaping to neighboring towns or territories. In spite of officers charged with maintaining order outside the city, like the Capitano del devieto at Reggio, there was no compelling police presence outside the city, and though statutory regulations required communites to aid in catching banniti, people were reluctant to involve themselves in these matters. ${ }^{32}$ The statutes show increasing concern with this problem, as the pecuniary penalites of the $1335 / 71$ and 1392 redactions for aiding banniti were replaced in 1411 with severe new penalties: those harboring banned persons or rebels should suffer the same penalty that the fugitive faced. ${ }^{33}$ One rare example of the enforcement of this statute can be found in 1400 , when a tavern-keeper was

26 BSR, Statuti, ms. 77, fol. 52r: “... si non comparverit habebitur pro confesso et convicto vere et legitime..."

27 Dean, Crime and Justice, 92.

28 Stern, Criminal Law System, 210.

29 Blanshei, Politics and Justice, 485.

$30 \quad$ BSR, Statuti, ms. 77, fol. 52r: "De modo citandi illos contra quos proceditur."

31 Desidero Cavalca, Il Bando nella prassi e nella dottrina giuridica medievale (Milan: Giuffrè, 1978), 173 .

32 Blanshei, "Crime and Law Enforcement," 124.

33 BSR, Statuti, ms. 77 , fol. 57r. If that punishment were corporal, then the punishment would be determined by the arbitrium of the Podestà. 
executed for receiving in his home men who had been banned for life from the commune, and giving them assistance. ${ }^{34}$

Like other procedural elements, procedures concerning the criminal ban were codified in local statutes, and there were significant variations in form and in consequence, reflecting diverse local useages. At Reggio, the bannum pro maleficio could be a pecuniary ban, lifted if the felon paid the penalty, ${ }^{35}$ or it could be further designated as in avere, meaning that the property of the felon was subject to confiscation. In its most serious form, the ban was proclaimed in persona, meaning the person could be assaulted with impunity. An allowable defense to a charge of murder was proof that the victim was under this type of ban. ${ }^{36}$

Property confiscation was not part of all criminal bans, but it was specifically indicated for some of them when the ban was pronounced in avere. Confiscations were paid to the treasury of the Visconti, not the city. ${ }^{37}$ In practice, it was possible for a convicted felon to protect assets even when placed under ban, because the same laws that protected heirs and creditors also protected families of the banniti. ${ }^{38}$ The confiscation process began immediately on the day the crime was discovered, and thus technically before the defendant was placed under ban. Probably this was an effort to freeze and inventory the assets. An inventory of all the movable and immovable property of the accused was to be completed within two days of the discovery of the crime, usually by the foreign notary of the criminal judge. The list was then sent for approval to the anziani or city council. Within eight days, the list was sent to Milan to the treasury officials.

After the property was inventoried, the Podestà ordered a public proclamation allowing any creditor one month to appear before the Podestà and produce a list of everything that she or he claimed to be owed by the condemned person (three months, if the creditor lived outside the jurisdiction, and six months if outside the territory of Milan). The first creditors were the families of the accused. Women could petition for the restitution of their dowries,

This case also demonstrates that the penalty in the 1411 statutes was in force before that redaction, as the 1392 and $1335 / 1371$ redactions institute pecuniary penalties, but here the judge was allowed to use his discretion to determine the penalty for harboring fugitives. The trial has been lost but the charge was restated in the record of his condemnation. ASRe, Giudiziario, Sentenze e condanne, no date but 1400, reg. 7, fol. 11.

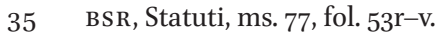

36 Carraway, “Contumacy, Defense Strategy, and Criminal Law," 124-128.

37 ASRe, Comune, Registri dei decreti, reg. 1385-1425, fol. 17r-v.

38 Carraway, “Contumacy, Defense Strategy and Criminal Law," 121-124. 
and children could petition for their due inheritance..$^{39}$ These claims were well established in law and protected by statute. The pars filii- the idea that the son had an interest in the patrimony even while the father still lived - was very much part of the medieval ius proprium, and the minimum provision due to heirs, the legitima, could not be denied even by testament. ${ }^{40}$ (Of course, this could cut both ways - if the son were the felon, his interest in the patrimony could be liable for confiscation as payment of the condemnation in a criminal matter. $)^{41}$ Debts, especially those owed to family members, protected the property of the contumacious felon..$^{42}$ No public instrument was required to prove a debt at Reggio Emilia: the process rested on fama, and legitimate proof of a debt consisted of the oath of two witnesses of good fama et opinio. The confiscators' interests were protected by the presence of two advocates representing Milan during the evaluation process and during the hearing of claims made on the property, but the burden of proof was theirs too, and they had to sue if fraud were suspected.

The most serious potential consequence of the ban was outlawry, which removed defendants from any protection of the law and meant they could be killed with impunity. This was of concern both technically-did it open the door to allow the murder of even those under ban for lesser crimes?and morally, because such a policy could be understood to sanction murder. ${ }^{43}$ The predominant opinion, however, was that very much like executioners, the

39 ASRe, Giudiziario, Atti e processi, n.d. but 1393, fols. 251r-256v. This petition, also from 1393, concerns the property of Guido and Cresembene de Albinea, who were banned from the commune. Lucia, wife of the banned Guido de Albinea, successfully petitioned the court for the restitution of her dowry. The mother of Guido and Cresembene was granted seventy florins, part of her dowry that had been assigned to her sons' use. Lucia's sons as well were granted the "first third" of the goods, after Lucia's dowry was subtracted. On women's legal rights and dowry restitution, see especially Julius Kirshner, "Wives' Claims against Insolvent Husbands in Late Medieval Italy," in Women of the Medieval World: Essays in Honor of John H. Mundy, eds. Julius Kirshner and Suzanne F. Wemple (New York: Basil Blackwell, 1985), 256-303. The rights of heirs were clarified under the rubric, "Quod ius creditorum et descendencium sit salvum." BSR, Statuti, ms. 77, fol. 6or.

Thomas Kuehn, Heirs, Kin and Creditors in Renaissance Florence (Cambridge: Cambridge University Press, 2008), 43, 70, and 189. This proposition that the son had claim on the goods of a living father beyond the peculium was debated. For a full discussion of this problem, see Manlio Bellomo, Problemi di diritto familiare nell'età dei comuni: beni paterni e 'pars filii' (Milan: Giuffrè, 1968), especially 111-153.

41 Bellomo, Problemi di diritto, 135.

42 Smail, The Consumption of Justice, 203.

43 Pazzaglini, The Criminal Ban of the Sienese Commune, 6o. Gandinus recognized that a statute allowing the murder of banned people with impunity might be strictly interpreted 
murderers of banniti served the public interest. In fact, in his support of this position, Nellus da San Gimigniano directly referenced the Ut fame. ${ }^{44}$ Local variation also characterized the category of outlawry. Reggio allowed banniti to be killed with impunity in the case of some capital felonies: homicide, arson, robbery, theft, treason, and kidnapping. ${ }^{45}$ At Perugia, people convicted of the lesser crime of assault with bloodshed could be killed with impunity; other cities like Vercelli allowed death only in cases of capital crimes. ${ }^{46}$ Venice even experimented, though not particularly successfully, with laws that allowed an outlaw to kill another outlaw in return for remission of his ban. ${ }^{47}$ The concept of the public interest in criminal justice, which was the foundation of inquisitorial procedure, alleviated even the moral consequences of killing.

For the banned felon, virtually all avenues to reintegration began with the existence of a peace agreement sworn with the victim's family. Again, significant local variation was the rule. At Bergamo, crimes committed without premeditation were eligible for relaxation of the ban. ${ }^{48}$ At Bologna in the thirteenth century, bans were sometimes cancelled based upon consilia that claimed procedural violations, or based on the existence of peace agreements. ${ }^{49} \mathrm{~A}$ fine had to be paid, though the terms of its payment could be adjusted over time, allowing a very small amount per annum. At Reggio, a year had to elapse between the crime and the first possiblity of reintegration. At that point, two conditions were necessary: a supplication to the lords of Milan to have the ban lifted and

to "permit the slaying of any bannitus condemned for a crime, including a non-capital offense, on account of his contumacy to the court."

44 Nellus, 2, 1, q.1. fol. 364v: "Primo ergo quaero, an valeat statutum quo cavetur bannitum pro maleficio posse impune occidi. Haec quaestio est multum nota, et trita, et propterea in ea non instabo. Concludens quod cum tale statutum fiat ad publicam utilitatem, tum ut homines a delinquendo terreantur, scientes se postea posse impune occidi, tum ut maleficia non remaneant impunita ... dicendum est tale statutum valere."

45 A statute concerning the same issue appears in the second book of the 1335/1371 redaction, which primarily concerns the offices of the commune, and the first book of the 1392 redaction, and was moved to Book Three in the 1411 redaction. ASRe, Comune, Statuti del 1335/1371, fol. 21v; ASRe, Comune, Statuti del 1392, fol. 146r; BSR, Statuti, ms. 77, fol. $17 \mathrm{v}$.

46 Dean, Crime and Justice, 105.

47 Gaetano Cozzi, "Authority and the Law in Renaissance Venice," in Renaissance Venice, ed. John Hale (London: Faber and Faber 1973), 319.

48 Vallerani, "Peace Accord and Trial," 186.

49 Giuliano Milani, "Prime note su disciplina e pratica del bando a Bologna attorno alla metà del XIII secolo," Mélanges de l'Ecole française de Rome. Moyen-Age, Temps moderns 109 (1997): 511-13. 
the sentence canceled, and a formal peace agreement with the victim's family. In times of crisis, the ban might also be lifted in return for military service. ${ }^{50}$

\section{Judicial Discretion in Punishment}

For those defendants who appeared to answer charges before the criminal judge, punishment was generally set by the statutes, though increasingly in the fourteenth and early fifteenth century, some room was occasionally allowed for the judge's discretion in punishment. Laurent Mayali traced the development of discretion in punishment among the jurists from the mid-twelfth to the early thirteenth century, showing that there was no clear agreement about discretionary punishment among the jurists. The issue was handled differently by Gratian, by the Justinian Code, and by papal decretals, and twelfth and thirteenth century jurists in turn interpreted these sources differently. ${ }^{51}$ In general, judges were bound less and less strictly to statutory penalties. To jurists like John of Faenza, the central point was that the sentence, statutory or not, had to be justified. ${ }^{2}$ Canonists and civilians came to agree upon a distinction between ordinary and extraordinary penalties: ordinary penalties were fixed by the canons or laws, while extraordinary punishments were determined by the arbitrium of the judge..$^{53}$ The jurist Huguccio developed a theory of discretionary punishment which declared that punishment should be fixed according to the seven criteria for consideration set forth in the Digest: "the motive, the person, the place, the time, the quality, the quantity and the outcome, 54 all of which elements (except motive) constituted the substantialia, which were crucial components of the denunciation. Allowing judicial discretion was politically very sensitive, and efforts to limit or expand the arbitrium of

50 ASRe, Comune, Registri dei decreti, reg. 1372-1375, April 2, 1373. In 1373, for example, a decree lifted the ban for anyone at Reggio banned for any crime including murder, excepting only treason, counterfeiting, or rebellion. The person must have been under ban for a year and must have made peace with the victim or with the heirs and friends of the victim ("heredibus et amicis defunctorum"). The term of service owed depended on the reason for the ban, and this term of service could be halved if the bannitus brought another person into service with him.

$5^{1} \quad$ Mayali, "The Concept of Discretionary Punishment," 303.

52 Mayali, "The Concept of Discretionary Punishment," 310.

53 Mayali, "The Concept of Discretionary Punishment," 305.

54 Dig. 48.19.16, quoted in Mayali, "The Concept of Discretionary Punishment," 312, and 312 n. 68 . 
the judges by the councils were caught up in the political struggles of the commune..$^{55}$

Two trends are noticeable in the statutory punishments at Reggio Emilia in this period: increased allowance for judicial arbitrium, and an increase in the complexity and sometimes the severity of punishment. The former was part of a general tendency in the fourteenth and fifteenth century to move towards discretionary punishment, which we find also elsewhere. In Modena in 1404, Niccolò III d'Este allowed the Podestà to penalize convicted criminals according to his judgment, and not as specifically set forth in the statutes, writing, "experience teaches that many crimes are committed that require harsher punishment than the law provides..." ${ }^{56}$ Bologna saw a shift to increased judicial arbitrium also at the end of the fourteenth century. ${ }^{57}$ While the foreign rectors at Reggio were bound by their oaths to observe the statutes, during the fourteenth century, the statutes themselves allowed increasing room for arbitrium to determine sentences. The 1411 statutes, redacted after the city became part of the Este dominion, shows a marked increase in allowances of arbitrium to determine punishments. Statutes which allowed arbitrium in sentencing increased during the fourteenth century from seven in the 1335/71 redaction to at least twenty three in the 1411 redaction.

When arbitrium was conceded to the Podestà in the 1335/71 and 1392 redactions, there were careful constraints. For example, under the statute "Concerning the penalty of he who throws someone on the ground in anger and strikes him with his feet," the judge had a window of twenty five pounds to penalize the culprit as seemed fitting for the particular circumstance of the crime, except that "lords can strike their grooms and servants without penalty, [but] only if they do not make them bleed. ${ }^{58}$ The seven statutes in the $1335 / 71$

55 See, for example, the situation at Perugia, in Vallerani, "How the inquisition is constructed," 238-241.

56 Quoted in Dean and Chambers, Clean Hands and Rough Justice, 26.

57 Blanshei, "Cambiamenti e continuità nella procedura penale a Bologna," (forthcoming).

58 ASRe, Comune, Statuti del 1335/1371, fol. 3ov. "De pena illius qui proiecerit aliquem in terra irato animo et eum percuserit cum pedibus.... Item, si quis aliquem in terra proiecerit irato animo et eum cum pedibus percusserit si fuerit miles vel filius militis puniatur in decem libras Rexanorum. Si fuerit pedes in centum solidos Rexanorum. Et quod potestas possit condempnare talem de iniquietem usque in quantitatem viginti quinque libras Rexanorum inspecta qualitate personarum salvo quod domini possint percutere scutiferos et pedissequas sine pena dummodo non faciant eis sanguinem." The 1392 redaction includes the same statute, adding only the final caveat, "idem, inteligatur de qualibet percussione facta inter domesticas personas si illud sibi non reputaverint ad iniuriam." ASRe, Comune, Statuti del 1392, fol. 151r. 
redaction giving arbitrium to the Podestà include blasphemy ${ }^{59}$ and assaults in which a person was pushed to the ground and kicked. ${ }^{60}$ His arbitrium could also be used to increase penalties for theft, ${ }^{61}$ or to mitigate or increase penalties for those who built and held others captive in a private jail. ${ }^{62}$ Two statutes allowed judicial discretion in determining penalties for speaking out against the actions of the commune or the lord, ${ }^{63}$ and for speaking in an unbecoming way of the lords of Reggio, or the Podestà, or the commune itself. ${ }^{64}$ Perhaps most significantly, he had the authority to determine a penalty when the statutes did not provide one. ${ }^{65}$

The 1392 redaction added judicial discretion in punishment to the statute "Concerning the penalty of he who says injurious words to anyone," 66 which was changed to include a final sentence allowing the Podestà the authority to increase the penalty up to 25 pounds imperial, "inspecta condictione iniuriam passi." ${ }^{\prime \prime}$ The 1392 redaction also added a clause to the statutes on false testimony that ordered anyone falsifying the seal of the signore of Reggio to suffer capital punishment, stating further that if someone falsified the seal of another party, they should be punished according to the arbitrium of the Podestà. ${ }^{68}$

An example of the limited nature of discretion in punishment that the statutes ceded to the Podestà is found in the law on blasphemy. The 1335 and 1392 statutes gave the judge perimeters for the punishment, which he could then determine after considering the individual who was charged: 69

Concerning the penalty of he who blasphemes God or the Blessed Virgin or other Saints. Rubric. Item, if anyone blasphemes or speaks ill of God or the Blessed Virgin Mary, or shows her a fish [sic] or says any other vulgarity (turpia) concerning God, the Blessed Virgin Mary or the Saints, let him be punished in the amount of ten pounds R.L. and for every other Saint, a hundred soldi R.L., and if he does not pay the said condemnation within ten days, on the third day let his tongue be cut out, or let him be beaten,

\footnotetext{
59 ASRe, Comune, Statuti del 1335/1371, fol. 27v and ASRe, Comune, Statuti del 1392, fol. 148v.

6 o ASRe, Comune, Statuti del 1335/1371, fol. 3ov.

61 ASRe, Comune, Statuti del 1335/1371, fol. 3ov.

62 ASRe, Comune, Statuti del 1335/1371, fol. 36r; ASRe, Comune, Statuti del 1392, fol. 153v.

63 ASRe, Comune, Statuti del 1335/1371, fol. $37 \mathrm{v}$.

64 ASRe, Comune, Statuti del 1335/1371, fol. 38 r.

65 ASRe, Comune, Statuti del 1335/1371, fol. $32 \mathrm{v}$.

66 ASRe, Comune, Statuti del 1335/1371, fol. $27 \mathrm{v}$.

67 ASRe, Comune, Statuti del 1392, fol. 149r.

68 ASRe, Comune, Statuti del 1392, fol. 152v.

69 ASRe, Comune, Statuti del 1335/1371, fol. $27 \mathrm{v}$.
} 
with the nature of the words and the person considered. And whoever is the accuser should have half the [money from] the penalty. ${ }^{70}$

If the blasphemer did not pay the penalty, the judge had to inflict corporal punishment but he could observe the nature of the crime and the "quality" of the person and use this information to influence his decision. His discretion only played a role in determining how severe the corporal punishment should be in the event of non-payment.

It is unclear whether judges always adhered closely to those limits placed on their ability to assign discretionary punishments. For example, in spite of the statute, penalties imposed for blasphemy varied widely. Paulus de Panzanowho was further noted as a man of mala fama - was sentenced to pay 25 pounds within ten days or have his tongue cut out and endure a public beating. ${ }^{71}$ But he was the only defendant charged with this crime to be threatened with corporal punishment. He is also the only blasphemy defendant designated as mala fama in the denunciation, and he is the only foreign defendant (he came from Modena). Other men accused of the same crime were sentenced to pay seven pounds, ${ }^{72}$ three pounds ${ }^{73}$ or five pounds. ${ }^{74}$ Even considering the mitigation for confession and for poverty, it is difficult to reconcile those amounts. If Niccolò d'Este was concerned that the court should have discretion to penalize more heavily, it seems that discretion could also be used to treat some defendants more lightly.

In both the $1335 / 71$ and 1392 redactions, the most important concession to the foreign rectors' arbitrium lay in their power to decide penalties for crimes not discussed in the statutes. In such cases, decisions were to be based on similar laws, so that the defendant would be punished "in the measure which is contained in that chapter to which it can best and better be compared, and not otherwise ... and if no similar statute can be found to which the upcoming

70 ASRe, Comune, Statuti del 1392, fol. 148v: "De pena illius qui blasfemaverit Deum vel Beatam Virginem vel alios Sanctos. Rubrica. Item, si quis deum vel Beatam Virginem Mariam blasfemaverit vel malgradaverit vel siccam ei ostenderit vel alia turpia de Deo, Beata Maria vel Sanctis dixerit puniatur in decem libras Rexanorum et pro quolibet alio Sancto vel Santa in centum soldos Rexanorum et si dictam condempnationem non solverit infra $\mathrm{x}$ dies tertiam diem abscidatur ei lingua vel verberetur inspecta qualitate verborum et persone. Et quilibet sit accusator et habeat medietatem bampni."

71 ASRe, Giudiziario, Libri delle denunzie, May 14, 1387, vol. 8, fol. 93.

72 ASRe, Giudiziario, Libri delle denunzie, Feb. 14 1402, vol. 19, fols. 33r-34v, and ASRe, Giudiziario, Libri delle denunzie, Feb. 20, 1408, vol. 21, fol. 79 .

73 ASRe, Giudiziario, Libri delle denunzie, Nov. 10, 1407, vol. 12, fol. 77 .

74 ASRe, Giudiziario, Libri delle denunzie, Apr. 4, 1407, vol. 21, fol. 67. 
case can be compared, then and in that case the penalty should be imposed by the discretion of the Podestà, after the quality of the crime and the character of the delinquent is considered, and [the quality of] the person against whom the crime was committed."75 In the 1392 manuscript, this statute is highlighted with maniculae, pointing hands that draw attention to the statute on the page, and marginal notes read "arbitria" and "ubi non est certa pena expressa arbitrio potestatis relinquitur." This sentiment seems far from the reluctance of the great republican communes of the thirteenth century to concede the power of arbitrium to the Podestà. ${ }^{76}$

The infrequent references to arbitrium and the limits placed upon it in the fourteenth century statutes make it all the more striking that the 1411 redaction includes judicial arbitrium in no less than twenty three criminal statutes. In some cases, judicial discretion still occurred within limits imposed by the statutes. The penalty for sodomy and incest, for example, ordered that the adult culprit should be immolated but minors who "can be excused because of their age" should be beaten and punished corporally (in persona) to a degree determined by the arbitrium of the Podestà. ${ }^{77}$ The punishment for witchcraft, which had no specific statute in the two earlier redactions, was left entirely to the judgment of the Podestà in the 1411 redaction, which declares that "Male and female witches should be punished with pecuniary and corporal punishments (in avere et persona) by the judgment of the Podestà, after the quality of the

75 ASRe, Comune, Statuti del 1392, fol. 152v: "De modo tenendo per potestatem et eius curiam in puniendo dellinquentes quando penna [sic] illius non veniat terminata in statutis et ut procedatur de similibus ad simillia. Rubrica. Statuimus et ordinavimus inviollabiliter esse observandum quod si aliquis casus venerit qui non sit comprehensus in superscriptis vel infrascriptis capitulis et inde certa penna non sit per statutum seu capitulum determinata quod ille qui fecerit malleficium vel quaxi de quo penna non fuerit ordinata puniatur in ea quantitate que continetur in ipso capitulo cui magis et mellius possit assimillari et non alliter et si contrafactum fuerit non teneatur ipso iure quod factum fuerit. Et hoc servari debeat sine tenore et quod si nullum statutum simille inveniatur cui casus obveniens assimillari possit tunc et eo casu imponatur penna arbitrio potestatis inspecta quallitate dellicti et persone dellinquentis et contra quam dellinquitur."

76 Vallerani, "How the Inquisition is Constructed," 238-239.

77 BSR Statuti, ms. 77, fol. 55v: "De pena sodomite et incestus. Si quis inciderit in crimen sodomie igne comburatur ita quod statum moriatur intelligendo agentem et pacientem in tali crimen incidisse et pena predicta punire debet nisi etas eos excusaret ut quia sint minores xiiii xiiii [sic] quo casu fustigentur et puniantur personaliter arbitrio potestatis comittens vero incestum usque ad tertium gradum computando gradum secundum ius canonicum capite puniatur." 
deed and the condition of the persons is inspected. ${ }^{78}$ Marginal notations in the manuscript indicate most of these statutes with a note of arbitrio. ${ }^{79}$

The second trend visible in the statutes is a strengthening of the severity of penalties. While the penalty for arson remained the same in all three redactions, the 1411 redaction was more complex, giving detailed orders on the payment of damages, and noting that the penalty stood whether the structure in question burned down entirely or was only damaged. ${ }^{80}$ The statute on homicide was augmented to include not only a death sentence, but also instructions for the confiscation of property (which was clearly already in practice during the fourteenth century). Homicide law in the 1335/71 redaction consisted of only two lines: "If anyone kills anyone, and if he can be captured and if he should come to the hands of the Podestà, the Podestà is obliged to have him killed by cutting off his head." ${ }^{81}$ The 1411 redaction, which details property law and bans, incorporated signorial decrees on the treatment of the goods of persons banned for homicide like those made by Giangaleazzo Visconti in 1387.82 In other cases, however, there were significant increases in penalties, in particular crimes involving social disorder. For example, the penalties for "he who runs to a fight" increased from a relatively modest fine of 25 pounds R.L. for a knight and 10 pounds for a footsoldier in the 1335/71 and 1392 redactions, to the loss of a foot in the 1411 redaction (if the culprit was a foreigner). ${ }^{83}$

The change from the 1392 statutes to the 1411 redaction, in both the allowance of arbitrium and possibly in the severity of punishments, appears sudden, but this is probably artificial. What appears to be a new severity may be in fact simply represent an articulation of existing practice. Witchcraft, for example,

78 BsR Statuti, ms. 77 , fol. 56v: "De maleficis. Malefici et malefice arbitro potestatis puniantur in haveri et persona inspecta qualitate facti et conditione personarum."

79 For some crimes, the penalties became much harsher during the fourteenth century and sometimes arbitrium was removed from the statutes instead of added. As the penalty for theft moved from a pecuniary fine to corporal punishment, judicial discretion disappeared from the statute, only to be reinstituted more broadly in the 1411 redaction.

80 ASRe, Comune, Statuti del 1335/1371, fol. 29v; ASRe, Comune, Statuti del 1392, fol. 15or; BSR Statuti, ms. 77 , fol. $59^{r-v}$.

81 ASRe, Comune, Statuti del 1335/1371, fol. 32r: "Si quis aliquem occiderit et capi poterit et in fortiam potestatis venerit teneatur potestas eum occidi facere amputando ei caput."

82 ASRe, Comune, Registri dei decreti, reg. 1385-1425, September 1, 1385, 17r-v. The confiscation of goods for homicide was common in Italian communes during the thirteenth and fourteenth century, and probably was common practice at Reggio before it was included in the statutes.

BSR Statuti, ms. 77 , fol. 63 v. 
was penalized corporally long before the 1411 redaction. ${ }^{84}$ The 1411 redaction reflects the new Este control of the city, but it seems clear the redaction took into account laws and practices already in force in the commune but not yet codified in the statutes. ${ }^{85}$ The trend seems clear-from 1335 to 1411 , more and more punishments were left, at least within defined parameters, to the discretion of the Podestà or his vicar, the iudex maleficorum.

The types of punishments given by the court of the Podestà were usually pecuniary and sometimes corporal. Pecuniary punishments could be mitigated by peace agreements, claims of poverty, and confession. Corporal punishments were sometimes transmutable for a fee. Capital punishments were often ordered for murder, arson, and treason, but, for reasons that are explored below, they were seldom carried out.

\section{Pecuniary Punishments}

The most common punishments were fines, which had fixed guidelines in the statutes. In some cases the statutes allowed the Podestà to decrease or increase the penalties in accordance with his discretion. The use of pecuniary punishments and their importance in limiting the sources of vendetta have long been well established. ${ }^{86}$ The court relied upon pecuniary punishments for all but the most serious felonies. Even in the case of such crimes as murder, while the penalty handed down was capital, the penalty exacted in reality was often the payment or partial payment required to have a ban lifted, and whatever losses were suffered as the result of the confiscation of property.

Pecuniary fines usually went to the municipal treasury, not to the wronged party, except in some specific instances like blasphemy, where the statutes decreed that the accuser should receive half the sum of the penalty. Money paid out as penalties was used in part to pay the salary of the Podestà (with the justification that this would motivate him to be zealous in the prosecution of crime. $)^{87}$ The 1392 redaction of the statute, which instituted penalties for

84 For examples, see ASRe, Giudiziario, Libri delle denunzie, July 28, 1374, and vol. 2, fol. 1or and following; June 21, 1388, vol. 9, fol. 76 and following. These cases are discussed more fully below. Both involve corporal punishment for the crime of witchcraft.

85 On modification of the statutes, see above, in Chapter Two.

86 Harold J. Berman, "The Background of the Western Legal Tradition in the Folklaw of the Peoples of Europe," The University of Chicago Law Review 45 (1978): 556.

87 ASRe, Comune, Registri dei decreti, reg. 1385-1389, July 17, 1386, Milan, 44v. “. . . in civitatibus nostris noviter aquisitis quia cognitum ex ipsis ipsos potestates se prontos et solicitos exibere ad delicta punienda que antea bene transibant inpunita." 
"he who says or said injurious words to anyone," preserved the penalties listed in the $1335 / 71$ redaction but gave the Podestà the authority to increase them if he desired. It also included an order that half the penalty should be paid to the offended party. ${ }^{88}$ Statutes on theft, on the other hand, ordered a penalty of 10 R.L. for petty theft, with the additional burden that the accused must restore to the victim double the value of the stolen property and his court expenses. However it appears that the penalty itself was payable to the city. ${ }^{89}$

The schema of instituting monetary fines underwent change during the fourteenth century. The $1335 / 71$ and 1392 redactions of the statutes show that the penalties followed a gradation according to status. Therefore a person convicted of "running to a fight" (curret ad rixam) would face a penalty of twenty five pounds if he were a knight, but only ten pounds if a footsoldier, a pedes. ${ }^{90}$ The statute was entirely rewritten in the 1411 redaction, removing the distinctions between miles and pedes, and giving the Podestà the power to punish the guilty party with penalties and corporal punishments (in havere et persona) by his own discretion. ${ }^{91}$ The fines imposed by the court were seldom the fines the accused paid, because the penalties could be mitigated for a number of circumstances, including the existence of a peace agreement between the offended party and the culprit, the confession of the accused, or the poverty of the convicted person.

\section{Shaming Punishments, Corporal Punishments and Capital Punishments}

When defendants were convicted, approximately 22 percent were sentenced to some manner of corporal or capital punishment. ${ }^{92}$ Most but not all of these were executions. Other means of corporal punishment included mutilation and shaming punishments. But nowhere near this many people were actually executed or otherwise corporally punished, because most corporal condemnations were handed down against defendants who were absent from the proceedings. Of these defendants, at least 71 percent were contumacious and subsequently placed under ban. Most corporal condemnations were never

88 ASRe, Comune, Statuti del 1392, fol. 149r.

89 ASRe, Comune, Statuti del 1335/1371, fol. 30v.

90 ASRe, Comune, Statuti del 1335/1371, fol. 29v, and ASRe, Comune, Statuti del 1392, fol. 15or.

91 BSR Statuti, ms. 77, fol. 63v.

92 Of a sample of 593 trials in which the defendant was convicted and the sentence is known. 
carried out, if for no other reason, than because the defendant was not to be found.

Shaming punishments appear very infrequently in the criminal records at Reggio. No instances of the use of pillories or other public shaming devices figure in the sentences from the criminal court, presumably because the court of the Podestà tried felonies, and those types of shaming punishments were not generally used in felony sentences. Shaming punishments sometimes inflicted physical pain and harm, but their real punitive value was in their degradation of the convicted person. ${ }^{93}$ For this reason, we should include the processions that accompanied witchcraft punishments, public beatings, and some physical mutilations in the category.

In certain instances described by the statutes or in the event that there was no statute to deal with a certain offense, the foreign rectors could use arbitrium to decide punishments. This was the case with convictions for witchcraft before 1411. In 1374, Gabriyna de Albetis stood accused not only of performing witchcraft herself, but of teaching spells and incantations to others. ${ }^{94}$ The statement of charges delineates spells that she taught to various men and women, most of which relate to love and sex. Women consulted Gabriyna for methods to keep their husbands in love with them and to ensure that their husbands would not leave them for their concubines, or to bring their absent husbands home. One woman, a certain Jacobina, entreated Gabriyna to teach her a spell that would make her husband stop beating her. Gabriyna recommended that Jacobina feed her husband some powdered chamomile, and afterwards, he would be gentle with her. ${ }^{95}$ Other were perhaps more controversial, as when she allegedly advised one woman who wanted her absent husband to return home to go to a secret place and, nude and on bended knee, declare "I adore you, Great Devil."96 Gabriyna was charged with fourteen separate crimes, some

93 I am borrowing here Martin Ingram's distinction, who considers "shame penalties" to be those punishments inflicted upon the body but designed chiefly as a public exhibition, as one end of a spectrum of corporal punishments from other penalties which aimed at causing physical pain. Martin Ingram, "Shame and Pain: Themes and Variations in Tudor Punishments" in Penal Practice and Culture, 1500-190o: Punishing the English, eds. Simon Devereaux and Paul Griffiths (New York: Palgrave Macmillian, 2004), 36.

94 ASRe, Giudiziario, Libri delle denunzie, June 28, 1374, vol. 2, fols. 1or-12r.

95 ASRe, Giudiziario, Libri delle denunzie, June 28, 1374, vol. 2, fol. 10v: “... docuit ipsam Dominam Jacobiam accipiere de pulvere camamille seu quod de camamilla pulvere faceret et daret ad comendum eidem Petro et quod ipse Petrus esset postea ipsi Jacobine mansuetus."

96 ASRe, Giudiziario, Libri delle denunzie, June 28, 1374, vol. 2, fol. $11 v$. 
as old as thirteen years. She confessed, and a marginal notation declares that not only was she branded, but also her tongue was amputated. ${ }^{97}$

In 1388, Henricus de Afamacavalo, a citizen of Reggio, made a querela alleging that Caterina, daughter of Boninus de Colorano,

... knowingly, treacherously and with aforethought, with a mind and intention for committing and perpetrating the misdeeds recorded here, instigated by a diabolical spirit, not having God or his mother the glorious virgin Mary before her eyes, but rather the enemy of the human race, with a blessed wax candle which she held in her hands she touched the said Henricus in the right arm, and, after she said certain diabolical words and incantations over this candle, about which it is better here at present to remain silent, she placed and buried this candle under the ground in a certain corner of the home near the bed where this Caterina was accustomed to lie, and thus it was that the said Henry was not able to carnally know any other woman; from which maleficia and diabolical operations thence the said Henricus was made unable to be with any other woman ...98

Caterina's alleged attack on Henricus's sexual abilities was punished severely by the criminal court. Once again, the discretion of the Podestà and the judge was used to devise her penalty:

The said Caterina should be beaten through the city of Reggio, and branded across the brow with a hot iron, and thence she should be placed on an ass with a miter on her head upon which should be painted images of the devil, whose works she followed, and she should be led through the city. ${ }^{99}$

97 ASRe, Giudiziario, Libri delle denunzie, 28 July 1374, vol. 2, fol. 1or.

98 ASRe, Giudiziario, Libri delle denunzie, June 21, 1388, vol. 9, fol. 76r-v: “... scienter dolose et appensate animo et intentione infrascriptum malleficium comitendi et perpetrandi spiritu diabolico instigata deum pro oculis non habendo nec eius virginem matrem gloriosam sed potius humani generis inimicum cum una candela de ceri benedicta quam habeat in manibus tetigit dictum Hericum in brachio dextro et dictis super ipsa candela certis diabolicis verbis et incantationibis que hic ad presens quam meliori tacenter ipsam candelam posivit et sepelivit sub terram in quodam angulo domus prope lectum ubi iacebat ipsa Caterina et hoc fuit ut dictus Henricus aliquam aliam mulierem carnaliter cognoscere non posset ex quibus maleficiis et diabolicis operationibus exinde dictus Henricus factus est inhabilis ad habendum rem cum aliqua alia muliere ..."

ASRe, Giudiziario, Libri delle denunzie, June 21, 1388, vol. 9, fol. 76v: “... dicta Caterina per civitatem Regii fustigetur et cum ferro calido in fronte buletur et exinde super uno asino 
Because Gabryina's punishment had similar elements to that of Caterina, it seems probable that she too suffered the procession and other shaming elements in the ritual of punishment, though we know only what the notary recorded in his brief marginal note.

Public beatings were another punishment that was intended both to inflict pain and to shame. Like the more elaborate punishments described above, public beatings were rarely ordered. I have found only three cases other than that those mentioned above in which the sentence was public beating. ${ }^{100}$ In all three cases, the defendants were mercenaries accused of theft, and two of them were German foreigners. Two of the men were also sentenced to the puncturing of an ear with hot iron. As in the witchcraft cases above, these punishments were intended to leave the convicted person with an enduring mark of their crime. Other corporal punishments ordered by the criminal court included the loss of a hand or foot if the condemned person were unable to pay their fine. These punishments were without exception handed down against convicted thieves and robbers.

\section{Incarceration}

Exactly when imprisonment became a mode of punishment and not simply a mechanism for pre-trial detainment is an issue that remains unresolved. Reacting to Foucault's assertions about the eighteenth-century birth of punitive imprisonment, ${ }^{101}$ scholars have explored the existence of punitive imprisonment in the early modern period, and have demonstrated that the origins of imprisonment may be found in the Church, as it developed means to deal with discipline issues within monasteries. By the twelfth century, imprisonment was used as a punishment for heresy. ${ }^{102}$ In Siena during the fourteenth century an advanced system of incarceration, where prisoners were separated by sex, social class, and type of crime, was already in use, though at Siena lifetime incarceration had not yet developed as a penalty. ${ }^{103}$ At Mantua, Dean

\footnotetext{
ponatur cum una mitria in capite super qua depinte sint ymagines diaboli cuius opera sequenta est et per ipsam civitatem conducatur..."

100 ASRe, Giudiziario, Libri delle denunzie, March 7,1375 vol. 2, fols. 46r-47v, ASRe, Giudiziario, Libri delle denunzie, October 25, 1376, vol. 3, fols. 120r-121r; ASRe, Giudiziario, Libri delle denunzie, March 26, 1377, vol. 4, fol. $5^{\text {r-v. }}$

101 Michel Foucault, Discipline and Punish: The Birth of the Prison, trans. Alan Sheridan, 2nd ed. (New York: Vintage Books, 1995).

102 Peters, Inquisition, 44.

103 Ascheri, "La pena di morte a Siena," 499.
} 
and Chambers noted a 1461 case of sacrilegious theft that earned its author a sentence of incarceration for life, ad perpetuos carceres. ${ }^{104}$ In his treatment of early modern imprisonment, Pieter Spierenburg commented that "the crucial difference between the Middle Ages and later periods is that in the medieval period these places were not primarily meant for punishment, though offenders might sometimes be imprisoned there." 105 He places the origins of punitive incarceration largely in the late sixteenth century. Geltner's recent study of prisons suggests that incarceration as a penalty was already well developed in the late medieval period. Even if punitive imprisonment received little treatment in legal texts of this period,- - and what discussion there was tended to be opposed to the practice - he argues that it was still used, and judges tended to hand down sentences of imprisonment especially as a substitute for fines, and as a penalty for some minor offenses. ${ }^{106}$

The prison at Reggio was used for pre-trial as well as post-conviction detention, though the records are not complete enough to allow us to speculate on how often it was used, and in what instances. We might hesitate to make assumptions based on the uses of imprisonment in other cities because, once again, there seems to be a fair amount of local variation, as Geltner's study of Bologna, Florence and Venice shows. At Trieste, imprisonment in the late fourteenth and early fifteenth centuries was used when major crimes were at issue in an inquisitorial process, and the jail housed largely either those who were awaiting the execution of their sentences or those whose trials were ongoing. ${ }^{107}$ At Reggio at the end of the fourteenth century, punitive imprisonment was not unknown, but we find it primarily used for those who could not post surety (defendants and perhaps also accusers) as well as an alternative punishment to a fine. The statutes directed that all who were able to provide surety or pay their condemnations should be released from jail within three days, unless they were accused of heresy, for which no surety would be sufficient. ${ }^{108}$ In 1378 , a certain Jacobinus was sentenced to pay either 300 pounds or stay six months

\footnotetext{
104 Dean and Chambers, Clean Hands and Rough Justice, 72.

105 Pieter Spierenburg, The Prison Experience: Disciplinary Institutions and their Inmates in Early Modern Europe (New Brunswick: Rutgers University Press, 1991), 8.

106 G. Geltner, The Medieval Prison (Princeton: Princeton University Press, 2008), 44-5.

107 Miriam Davide, "La giustizia criminale" in Medioevo a Trieste: Istituzioni, arte società nel Trecento, ed. Paolo Cammarosano, Atti del Convegno Trieste, 22-24 Novembre 2007 (Rome: Viella, 2007), 242.

108 ASRe, Comune, Statuti del 1335/1371, fol. 25v, "Quod qui de heresi fuerit accusatus non tradatur alicui pro securitate sed in carcere et sub fida custodia recludatur nec inde extrahatur nisi fuerit absolutus..."
} 
in jail for an assault. ${ }^{109}$ Antonius de Pedemonte, a tavern owner, found himself in a similar situation when he was sentenced to 200 pounds for an assault and a further hundred pounds for bearing arms. Alternatively, he too could spend six months in jail. ${ }^{110}$ Marchus, son of Petrus de Ferrara, was fined twenty gold florins for carrying arms at night in the city without a license. ${ }^{111} \mathrm{He}$ could not pay the fine and spent four months in jail, after which his sentence was cancelled. ${ }^{112}$

The jail at Reggio also housed convicted criminals awaiting corporal punishment. How long people sentenced to corporal punishment might spend in jail awaiting the execution of their sentences varied. Some corporal punishments were inflicted on the day they were handed down, while in other cases, it appears that the defendants were incarcerated for months between conviction and punishment. A certain Nicholaus, a Hungarian man accused of theft, was convicted in January of $1376 .{ }^{113}$ In May of that year, three custodians of the city jail were tried for negligence for allowing some inmates to escape, one of whom was Nicholaus, still apparently in jail months after his sentencing. ${ }^{114}$ Inmates were detained for many different reasons, not all criminal, and it appears they were housed together-the convicted together with those awaiting trial, the debtor together with the thief and the murderer-because they sometimes planned escapes together. It seems likely that female inmates would have had some separation. Women were not infrequently remanded to jail by the criminal judge, and apparently, like men, they served time in the jail as a substitute for fees if they were unable to pay. The prostitute Margarita de Alamania, for example, stayed in jail for two months after a quarrel with another woman because she could not pay her fine. ${ }^{115}$

A surviving list of inmates shows twenty-seven people held for a variety of reasons and at the orders of various city officials, or "ad petitionem" of people that made complaints against them. ${ }^{116}$ People were incarcerated for debt, for non-criminal offenses, and for reasons that are not immediately apparent from the records, such as Andriolus de Manfredis who was held in the jail because of an unspecified order made by the Podestà and the Captain of Reggio at the

\footnotetext{
109 ASRe, Giudiziario, Libri delle denunzie, April 14, 1378, vol. 4, fols. 83r-84v.

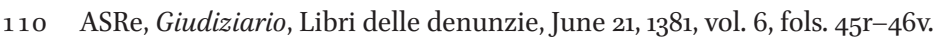

111 ASRe, Giudiziario, Libri delle denunzie, June 8, 1389, vol. 12, fols. 91r-92v.

112 ASRe, Giudiziario, Sentenze e condanne, reg. 2, fasc. 3, fol. 18r-v.

113 ASRe, Giudiziario, Libri delle denunzie, January 9, 1376, vol. 3, fols. 12r-14v.

114 ASRe, Giudiziario, Libri delle denunzie, May 20, 1376, vol. 3, fols. 69r-7ov.

115 ASRe, Giudiziario, Atti e processi, n.d., 1374, fol. 571 .

116 ASRe, Giudiziario, Atti e processi, May 3, 1374, fol. 569 r.
} 
will of Barnabò Visconti, de conscientia magnifici domini domini nostri. ${ }^{117}$ The jail also could be used to house the insane. The Podestà was required to make an inquest into the presence of the insane in his jurisdictions, and if the insane person had no family to assume his or her care, then they were to be incarcerated and chained, and fed with alms. ${ }^{118}$

No records survive to describe conditions within the jail. Like prisons in Bologna,Venice and Florence - indeed, likemost municipal medieval prisonsthe jail was urban, connected to the city and part of city life. ${ }^{119}$ It was situated near the palazzo di comune, on the edge of, or perhaps over, a canal. There was therefore some concern about the inmates' safety in times of heavy rain, probably for fear of flooding. ${ }^{120}$ While imprisoned, the convicted persons or those awaiting trial had the right to a certain quality of treatment. By 1411, this was legislated in the statutes under the rubric, "The penalty of a guard of the jail oppressing unduly those who are incarcerated:"

The guard or superintendent (superstans) of the jail of the commune of Reggio should not fetter or place in fetters or hold someone in a putrid place without the license of the Podestà or other official upon whose order he is detained, nor should he withhold or deny food or drink or clothing or a bed to that person, nor should he make any other trouble or harshness beyond the customary recommendation and usual guardianship. And let he who does otherwise be punished for whatever [violation] in turn, in the amount of ten pounds R.L. and more or less according to

117 ASRe, Giudiziario, Libri delle denunzie, May 20, 1376, vol. 3, fols. 69r-7ov.

118 ASRe, Comune, Registri dei decreti, reg. 1385-1425, July 26, 1384. "Quia furiosorum dementium sive mentecaptorum actus per quos nil nisi detestabile potest insurgere supermodum et incomperabiliter aborremus fecimus ideo multis iam annis elapsis contra eosdem actus per nostrum decretum specialiter provideri, quod ex precessorum tuorum neglienda iam in desuetudinem nobis abisse videtur cum nulla lege cohertiti per iurisdictionem tibi comissam. Sentiamus ipsos ultrum citroque discurere pro libito voluntatis quare providere volentes quantumcumque nobis possible sit quod dictorum furiosorum dementum sive mentecaptorum actus onitus reprimantur. Mandamus tibi quatenus decretum nostrum incluxi tenoris, quod aliax per nos misum nunc iterato examinari et corigi fecimus pro ut nobis expediens visum fuit in tota iurisdictionem per nos tibi commissa. Serves prout iacet et facias inviolabiliter observari rescribendo nobis statim de receptione presentium. Datum Mediolani die xxvi July 1394."

119 Geltner, The Medieval Prison, 28-29.

120 ASRe, Comune, Proviggioni, August 12, 1390, vol. 9, fol. 22v “... providerunt et ordinaverunt quod massarollus comunis Regii faciat voluere scallam carcerum et ipsam talliter recaptare quod non ledantur carcerati ab aliqua pluvia quando pluit." 
the judgment of the Podestà or the judge, with the quality of the deed and the character of the person being considered. And every eight days, the Podestà is bound to go or send [someone] to inquire at the jails how things are done by the guard or the supervisor of the jail. ${ }^{121}$

The sporadic evidence remaining about Reggio's late medieval jail includes several lists of inmates made at the request of the Podestà, perhaps indicating that the provision in the statute that obliged the Podestà to conduct regular checks on the jail was already in place before $1411 .{ }^{122}$ No charges made against jailers for the mistreatment of prisoners survive, though whether this indicates that the problem was not widespread or that it was not prosecuted remains an open question.

The guards of the jail had a great deal of legal responsibility. They were responsible for bringing their detainees to court on the appointed days, and could face severe penalties for failure to do so. Johannes Spadario, the jailer in 1376, was threatened with a ban for not bringing to the court at the appointed time a man accused of murder, ${ }^{123}$ and the threat apparently produced results, as the man appeared in court some weeks later and was then executed. ${ }^{124}$ The judges handed the defendants into the custody of a jail guard, who conducted them to the prison. If the defendants escaped, these guards then became responsible for the amount of the fine the defendants would have faced had they been convicted. It is difficult to imagine how a guard's salary could compensate for this risk. In addition to facing serious financial penalties if they failed at their duties, guards undertook some element of personal risk too, as they were sometimes injured in escape attempts. ${ }^{125}$

121 BSR Statuti, ms. 77, fol. 64v: "De pena custodis carcerum gravantis carceratos indebite. Custos seu superstans carcerum comunis Regii non debeat aliquem detentum vel carceratum inbogare vel ponere in cepis vel in loco putrido tenere sine licentia potestis vel illius officialis cuius precepto detentur fuerit nec cibum vel potum vel panos seu lectum carcerato auffere nec denegare persone vel alium nec aliquod gravamen vel asperitatem ultra solitam recomendatam et ordinatam custodiam facere et que contrafecerit puniatur pro quolibet et qualibet vice in libras decem Rexanorum et plus et minus arbitrio potestis vel iudicis considerata facti qualitate et personarum condictione et potestas singulis octo diebus teneatur ire vel mittere ad inquirendum a carceratis qualiter tractantur a custode vel superstite carcerum."

For example, see ASRe, Comune, Atti e processi, 1379, fol. 569r; ASRe, Atti e Processi, 1389, 571v-572v; ASRe, Atti e Processi, n.d., 1394, unnumbered folios.

123 ASRe, Giudiziario, Libri delle denunzie, September 1, 1376, vol. 3, fol. 99v.

124 ASRe, Giudiziario, Libri delle denunzie, October 23, 1376, vol. 3, fol. 116r.

125 As happened on January 20 1390. ASRe, Giudiziario, Libri delle denunzie, January 20, 1390. 
In general, medieval prisons were not particularly closely guarded, and jailers were not particularly well compensated, perhaps leaving them open to corruption. ${ }^{126}$ The above-mentioned Andriolus de Manfredis escaped together with a certain Jacopinus de Rio Sanguinaria and three other men, who had been convicted of theft and were awaiting the execution of their sentence (they were to have their ears punctured with an hot iron, and then they were to be "fiercely beaten"). ${ }^{127}$ All escaped together along with the guards, who were accused of negligence in their duties and convicted in absentia. In other cases, people escaped jail when they managed to steal the keys to the jail from their guards. One guard was sentenced to pay the staggering sum of 260 pounds. He was not able to pay, and was therefore himself sent to jail. ${ }^{128}$ In another example, three men stole the keys from their jailer, but were still not able to open the door. They finally managed to break the lock and ran through the city in the middle of the night until they reached the walls, where they stole a ladder, climbed over the walls, swam through the moat, and disappeared into the night. The jailer, faced with a fine of 200 imperial pounds for his negligence, apparently ran too-he never answered the charges in court. ${ }^{129}$ Other escapees were not so fortunate. An inquisition against another would-be fugitive was ended when his drowned body was pulled from the moat. ${ }^{130}$ In 1396, the jail was the scene of another dramatic - if unsuccessful — effort at escape. Two men imprisoned for an assault and one man imprisoned for debt drew up "a plan [which] was made and shared among the three of them for breaking out of the aforesaid jail."131

With a piece of iron which they stole from a certain iron grate which was in the canal that runs through the said jail, broke the wall of the said jail and went into the said canal, and with that same piece of iron they shattered and broke the walls of the workshop in which works Tomaxinus de Acerbo, a blacksmith, and in such a way, that from the said canal they went into this workshop from the canal and fled from the said jail. 132

\footnotetext{
126 Geltner, The Medieval Prison, 76.

127 ASRe, Giudiziario, Libri delle denunzie, May 20, 1376, vol. 3, fol. 67r.

128 ASRe, Giudiziario, Libri delle denunzie, October 20, 1376, vol. 3, fol. $115 \mathrm{r}-\mathrm{v}$.

129 ASRe, Giudiziario, Libri delle denunzie, October 16, 1377, vol. 4, fols. 49r-5ov.

130 ASRe, Giudiziario, Libri delle denunzie, May 7, 1376, vol. 3, fols. 87r-88v.

131 ASRe, Giudiziario, Libri delle denunzie, September 28 , 1396, vol. 15, fols. 172r-175v: “. . . facto et participato conscilio inter ipsos tres de rompendo et fragendo carceres predictes..."

132 ASRe, Giudiziario, Libri delle denunzie, September 28 1396, vol. 15, fol. 172r: “... cum uno ferro quem abstulerunt de quadam grata feri que est in canali quod decurrit per dictos carceres fregerunt murum dictorum carcerum et in dictum canale[m] intraverunt et de
} 
Two of the men were caught and confessed their actions; the judge then questioned them about how well they had been guarded while they were in jail. They replied that three men were assigned to the jail that day. Two were nowhere to be seen, and the third was carrying a bucket of water back to the jail when the two made their escape. The escapees were sentenced to be publicly beaten. ${ }^{133}$ This was the only recorded instance in which the escapees were caught. Contumacious escapees were usually placed under a ban of a thousand pounds imperial, and sentenced to death in absentia.

In conclusion, incarceration at Reggio, as elsewhere, was used for a variety of purposes, and while jail sentences were not given in place of other means of punishment, it does appear that many convicted criminals were incarcerated as an alternative to fines they could not pay. So in practical terms, incarceration was a penalty used in lieu of fines even in cases when the accused was not sentenced to it. Capital punishment, however, was handed down as a sentence far more often than it was carried out.

\section{Capital Punishments}

The value of the capital sentence for the municipal authorities lay as much in its publication as in its execution. Sentences of death were read publicly by the nuncii in the central piazza of the city. This was an assertion of public authority. Execution itself, however, was a relatively rare occurrence. When executions were carried out, their value as deterrents was exploited as much as possible, and sometimes the records tell us that the condemned man was executed in exemplum, as an example for others.

Municipal statutes placed strict limits on capital punishment. When statutes allowed the judge to impose penalties with his own arbitrium, he could order punishments that harmed the body but he could not by his own discretion sentence someone to die unless a capital penalty were provided for in the statutes. These were not the only limits on capital punishments. ${ }^{134}$ Minors could not be subject to any corporal punishment, and if they committed crimes

ipso canali cum eodemmet [sic] ferro ruperunt et fregerunt murorum stationis in qua laborat Tomaxinus de Acerbo ferarius ita et taliter quod de dicto canali in dictam stationem intraverunt et de dictis carceribus affugierunt..."

133 ASRe, Giudiziario, Libri delle denunzie, September 28, 1396, vol. 15, fols. 172r-175v.

134 BSR Statuti, ms. 77 , fol. 5 2v-53r: “... nullus pro aliquo malleficio vel delicto puniatur vel puniri possit corporaliter nisi a lege municipali caveatur sed puniatur in havere arbitrio potestis inspecta condictione persone et qualitate delicti et non intelligatur per legem 
for which the penalty would normally cause blood to flow, their sentence was commuted to a pecuniary penalty left to the Podestà's discretion:

Item, that no one who, having committed a crime, is not older than fourteen years, can be punished corporally; rather that person can be punished financially, according to the judgment of the Podestà, with the kind of deed and the condition of the person having been inspected. ${ }^{135}$

The 1411 redaction of this statute allows the Podestà to sentence these minors to jail instead:

... the Podestà can condemn the person to stand in jail for the offense for a time which seems appropriate to him, after the offense and wrongdoing are considered. ${ }^{136}$

Sentences of death and dismemberment were determined with the counsel of other foreign officials, and at least nominally with the consent of the public assembly. For example, Martinus de Colonia was captured and executed in July of 1397, having already been convicted of no less than seven crimes, including adultery, theft and assault, for which he was under ban for life from Reggio. His death sentence was promulgated by Podestà "with the will and deliberation of the above-mentioned Vicar, the Iudex Maleficorum, and of the said Iudex Rationis, and other officials of the court of the aforementioned Lord Podestà, in the public and general assembly of the men and persons of the said city ..." The death sentence was read aloud and publicly in the vulgar tongue by the notary. ${ }^{137}$ The Podestà ordered that

municipalem cautum esse ubi in aliquo statuto reperiretur quod aliquis puniri deberet in havere et in persona arbitrio potestatis."

135 ASRe, Comune, Statuti del 1392, fol. 157v: "Item quod nullus qui non sit mayor quatuordecim annis comittens malleficium possit puniri in persona sed puniatur in avere arbitrio potestatis inspecta qualitate facti et condictione personarum."

136 BSR, Statuti, ms. 77, fol. 6or: "Statutum et ordinatum est quod nullus minor quatuordecim annis possit puniri corporaliter sed puniatur in havere arbitrio potestatis inspecta qualitte facti et conditione personarum. Posit tamen Potestas ipsum condemnare ad standum propter hoc in carceribus vel ad tempus secundum quod sibi placuitum [sic] et videbitur inspecta malleficii et offensi."

137 ASRe, Giudiziario, Sentenze e condanne, July 18, 1397: "Lata data et in hiis scriptiis similiter pronuniciata et promulgata fuit superscripta condempnatio corporalis et sententia condempnata corporalis per superscriptum Dominum Potestatem pro tribunali sedentem super quodam bancho [...] super arengheria palacii novi comunis Regii cum voluntate et 
the said Martinus should and must be led to the customary place of justice, and there he should be suspended with a noose by the neck from the gallows in such a way that he dies, and his soul is separated from his body, so that his death might become an example for others. ${ }^{138}$

Whatever goods Martinus possessed were also to be confiscated. Martinus himself was a foreigner, de Lamania being a common corruption of de Alamania. He was accused of multiple crimes and was clearly believed to be a career criminal. This is in keeping with the trend in the late fourteenth century for capital sentences to be used disproportionately against recidivists and foreigners. ${ }^{139}$ His public death was intended to serve as a deterrent.

Once the sentence was determined by the foreign rectors, orders were given to another official to arrange the details. These men have various titles, sometimes dominus or miles. Martinus's execution was entrusted to a man who may have been the "knight of justice" of the commune:

We entrust the execution of this sentence to the wise man Lord Filipus de Vigevano, whom on this occasion we choose to act on our behalf, ordering to the said Filipus that he should effectually order this our present sentence to execution, and he should report to us concerning the abovementioned execution. ${ }^{140}$

The executioner himself is unnamed and his office is unmentioned in records and in municipal law. The people who served as executioners sometimes held

deliberatione superscriptorum vicari iudici malleficorum et dicti iudicis rationis et aliorum officialium curie prefati domini potestis in publica et generale contione hominium et personarum dicte civitatis sono campane et sono tube ac voce preconia ut moris est congregati et convocati in platea comunis dicte civitatis et super arengheria predicta. Et scripta lecta publicata et vulgarizata per me Johannem de Calchaguis notarium infrascriptum de mandato consensu et voluntate dictorum dominorum potestatis et iudicium et officialium curie prefati domini potestatis ..."

138 ASRe, Giudiziario, Sentenze e condanne, July 18, 1397: "Quod dictus Martinus ducatur et duci debeat ad locum justicie ordinatum et ibi furcis per gullam laqueo suspendatur taliter quod omnino moriatur et anima a corpore separetur ut eius mors ceteris transeat in exemplum."

139 Blanshei, "Crime and Law Enforcement," 123.

140 ASRe, Giudiziario, Sentenze e condanne, July 18, 1397: "Executionem cuius sententie comittimus prudenti viro domino Filipo de Vigevano quem in hac parte ellegimus pro colaterali nostro mandantes dicto domino Filipo quatenus hanc nostram presentem sententiam debeat effectualiter executioni mandare et nobis de executione predicte referre debeat." 
their unenviable employment as a result of their own crimes. As convicted criminals, they sometimes had to be escorted to the places of justice because they might try to escape. ${ }^{141}$ Executioners held their offices because they were sentenced to them for a term of years: their horrific duties were understood as a punishment. A late fifteenth century case in Mantua showed an executioner balk at his orders to execute a convicted woman. The Marquis of Mantua, Ludovico Gonzaga, threatened that if he refused to carry out his order, the woman would be pardoned and ordered to execute him instead. ${ }^{142}$

Men and women of all social classes might receive a sentence of capital punishment, but the sentences were disproportionately carried out against the lower strata of society, mercenaries and foreigners. Defendants who were mercenaries or vagabundi figure prominently in the list of defendants sentenced to corporal and capital punishment, but they are accompanied, admittedly more rarely, by defendants who appear to be of higher status, even nobles. However, sentencing defendants to death was one thing; executing them was quite another, and in fact, the fulfillment of capital sentences was very rare at Reggio.

As a revision of the nineteenth-century image of the medieval court as a place of frequent executions, some scholars have argued that in fact, medieval courts were loath to use capital punishment unless the circumstances of the crime were particularly heinous. ${ }^{143}$ Neither image is true for Reggio. Capital punishment was carried out at Reggio, though it was reserved for the crimes of murder, witchcraft, arson, rape, theft, and treason. Particularly murder and arson convictions resulted in every case I have examined with an order for capital punishment.

It is not possible to offer a reliable quantified analysis of the number of death sentences that were imposed and carried out because the condemnation records from Reggio survive only sporadically and only for a period encompassing a little more than ten years, with lacunae. The marginal notations in the trial records sometimes reveal whether a sentence was carried out. Of the surviving trials where the sentence was death and where the outcome is known, approximately 15 percent of death sentences were carried out. (This number includes defendants sentenced to death in absentia.) Yet most defendants sentenced to death were contumacious, and they might have been executed years after the sentence was proclaimed, while trial records reveal

\footnotetext{
141 Chambers and Dean, Clean Hands and Rough Justice, 75-6.

142 Chambers and Dean, Clean Hands and Rough Justice, 120.

143 R. Lavoie, "Les statistiques criminelles et le visage du justicier: justice royale et justice seigneuriale en Provence au Moyen Age," Provence historique 28 (1979): 15-18.
} 
nothing about summary executions for notorious crimes. However research in other cities would support the impression that executions were rare events. In Milan for the period 1385-1429, of seventy-one condemnations to death in the surviving sentences from $1385^{-1429}$, only thirteen were actually carried out: two for homicide, seven for theft, one for false witness, and three for heresy. ${ }^{144}$ In Florence in the second half of the fourteenth century, an average of between eleven and thirteen executions per year were carried out, which fell by the fifteenth century to seven or eight. ${ }^{145}$

In theory, capital punishment was both a sign of and an instrument of good government. ${ }^{146}$ Executions could be maximized for their value as political propaganda. Esther Cohen, in her study of late medieval Paris, saw what she interpreted as a strong inconsistency in types of penalties meted out for the same crimes. Some ended in fantastical executions, while many more ended in pecuniary penalties or royal pardons. This prompted her to write: “... the exact retribution to each offender mattered little to the authorities. What mattered was the effect of this retribution upon the rest of society. The logical consequence was that, while punishment must be seen to be done, it need not always necessarily be done. It served no purpose publicly to penalize the petty, unspectacular offender, but the public ritual of one spectacular execution might be more useful in many ways than the systematic application of law to all."147

Cohen's astute observation about the theatrical use of public execution shows the value of capital sentences as deterrents, even when they were not carried out frequently or systematically. Because the authority of the sword, the merum imperium, was the highest level of jurisdictional autonomy, these public executions were doubtless reassertions of territorial rights as well.

\section{Mitigation and Instrumenta Pacis}

Confession was not the only possibility for mitigating penalties: a penalty could be mitigated by another quarter if the accused made peace with the

\footnotetext{
144 Verga, "Le sentenze criminali dei podestà milanesi," 130.

145 Zorzi, "The judicial system in Florence," 54. See also Zorzi, "Le esecuzioni delle condanne a morte a Firenze nel tardo medioevo tra repressione penale e cerimoniale pubblico," in Simbolo e realtà della vita urbana nel tardo medioevo, ed. Massimo Miglio (Rome: Vecchiarelli, 1993).

146 Ascheri, "La pena di morte," 489.

147 Cohen, "To die a criminal for the Public Good," 287.
} 
victim. This was done through formal agreements, either written or oral, that forgave offenses and declared a peace between the parties that was punishable by law if either violated it. Though the particular written form of these documents emerged in the thirteenth century, the roots of the practice may have had its origins in early Germanic law that sought in a similar way to limit the vendetta. ${ }^{148}$

Peace agreements were not contracts and they contained no reciprocal agreements. They were, in form, more similar to gifts. ${ }^{149}$ Indeed a marginal notation on the 1411 redaction of Reggio's statutes conceives of the formal peace as a type of gift: the anonymous writer, citing Dinus, explains that peace is like a gift given. He also references Augustine's De civitate Dei XVIII, in which Augustine wrote that peace is a gift given by the conquered to the stronger party that defeated them, in hopes of lessening the violence. ${ }^{150}$ Surely these agreements could play a role in restoring order after conflict, especially when the community became involved in bringing the parties to agreement. ${ }^{151}$ However, in the medieval culture of honor and shame, and of feud and vendetta, the enaction of the peace was probably not always or perhaps even often an altruistic gift. After all, assailants sometimes needed encouragement to accept the "gift" of peace, at least in the form of a reduced penalty, and even then, peace agreements were not always welcome. At Marseilles, Daniel Smail noted a case of a man whose victim taunted him from outside the jail, saying, "unless you make peace with me, I will ensure that you lose a foot or a fist." ${ }^{152}$ This does not sound much like a gift.

The role of formal peace agreements in the criminal courts of late medieval Italy is difficult to generalize because the efficacy of these agreements to halt proceedings or mitigate penalties changed over time and also varied in different cities. The function of the instrumentum pacis in criminal proceedings was determined by statute. Peace agreements played the strongest role in criminal proceedings in municipal statutes from the twelfth and thirteenth centuries,

148 Katherine L. Jansen, Peacemaking in the Oltrarno, 1287-1297," in Pope, Church and City: Essays in Honour of Brenda M. Bolton, eds. Frances Andrews, Christoph Egger and Constance M. Rousseau (Leiden: Brill, 2004), 331.

149 Many peace agreements transacted before the court were technically remissione, which absolved the offender for liability for injuries. Glen Kumhera, "Making Peace in Medieval Siena: Instruments of Peace, 1280-1400," (Ph.D. diss., University of Chicago, 2005), 65. Kumhera gives extensive treatment to the form and function of these agreements in the courts.

150 BSR, ms. 77, 66r.

$15^{1}$ Jansen, "Peacemaking in the Oltrarno, 1287-1297," 343.

$15^{2}$ Smail, The Consumption of Justice, 116. 
during which period they often could be used to stop an ongoing trial; during the fourteenth century, together with the rise of inquisitorial procedure in the courts, there was a general tendancy to limit their efficacy to stop the trial process, especially when the offense was a blood crime. ${ }^{153}$ Generally speaking, statutes did tend to limit which crimes could be resolved or partially resolved with a peace agreement: some excluded sodomy, like Grosseto, others homicide, robbery and theft, like Bergamo and Siena, as well as Perugia, which also excluded forgery, breaking a truce, and some assaults. ${ }^{154}$

A fair amount of local variation existed in the relationship between peace agreements and ongoing criminal processes. In late medieval Florence, the instrumentum pacis was allowable as an exception in some criminal cases. If the parties contracted their agreement within fifteen days of the commission of the crime, the public trial was abrogated. ${ }^{155}$ At Milan, a peace agreement absolved the offender from the portion of the fine that would eventually go to the offended party, but it could not absolve him from paying the portion owed to the city coffers. ${ }^{156}$ In Siena, Parma, and Grosseto, a peace agreement could remit the entire penalty. ${ }^{157}$ At Siena, where the peace could abrogate a trial, it was used with great frequency: one sample shows that 223 of 330 inquisition trials were dismissed because of the presentation of a peace agreement. ${ }^{158}$ At Reggio, as we shall see, the peace agreement mitigated the penalty by one quarter but it did not stop a proceeding or cancel a process.

These distinctions are extremely important, because whether the parties in dispute had the power to end the process before sentencing determined how much risk was borne by the accuser or person making a querela in the course of the criminal trial. The ability of parties in conflict to negotiate an end to the trial is no less significant than the ability of a modern prosecutor and defendant to reach a plea bargain. The fact that Reggio did not allow parties in

153 Marco Bellabarba, "Pace pubblica e pace private: linguaggi e istituzioni processuali nell'Italia moderna," in Criminalità e giustizia in Germania e in Italia: Pratiche giudiziarie e linguaggi giuridici tra tardo medioevo et età moderna / Kriminalität und Justiz in Deutschland und Italien: Rechtspraktiken und gerichtliche Diskurse in Spätmittelalter und Früher Neuzeit, Annali dell'Istituto storico italo-germanico in Trento. Contributi 11; eds. Marco Bellabarba, Gerd Schwerhoff, Andrea Zorzi (Bologna: il Mulino, 1999), 200.

154 Glenn Kumhera, "Promoting Peace in Medieval Siena" in War and Peace: Critical Issues in Euroepan Societies and Literature, 800-180o, eds. Albrecht Classen and Nadia Margolis (Berlin: De Gruyter, 2011) 338-39.

155 Stern, Criminal Law System, 27.

156 Verga, "Le sentenze criminali dei podestà milanesi," 117-118.

157 Kumhera, "Promoting Peace in Medieval Siena," 337.

$15^{8}$ Kumhera, "Promoting Peace in Medieval Siena," 342. 
conflict to settle the dispute outside court after the inquisition began, together with the requirement, in the case of a querela, that the accuser post personal surety, must together have discouraged use of the criminal court as a place to air disputes. This raises the question of how the use of peace agreements - either to mitigate a penalty or to set it aside altogether, as at Siena - fit inside the bigger theoretical picture of punishment, as the inquisitorial trial was based on the idea of public interest: interest civitati ne crimina remaneant impunita, as opposed to punishment interest alcui. ${ }^{159}$ This wide allowance of peace instruments to mitigate penalties or abrogate trials, especially when placed beside the role of private parties in inquisition trials, shows once again that inquisitorial procedure in practice retained features of the older process.

One of the most important examinations of peace agreements and legal procedure is Massimo Vallerani's study of the system of peace agreements in thirteenth century Perugia. Vallerani isolated three primary motivations for government authorities to allow the peace: it provided a way for people to have their bans lifted and return to the community, it concluded violent actions with a promise for stable peace, and it limited the new sources of vendetta which could arise from these actions. ${ }^{160}$ At Bergamo, certain crucial aspects of the crime determined whether a convicted person was eligible for recall from a homicide ban. Only those crimes committed without premeditation were eligible for relaxation of the ban. At Bologna, a recall for homicide came with a fine, but that fine could be delayed or spread over time so that the culprit paid a very small amount per annum, sometimes around 20 soldi. At Perugia, peace agreements were effective only in the case of certain crimes. If a peace agreement was concluded within eight days, the Podestà and the city captain could not proceed to sentencing except in the cases of the most extreme crimes, including murder, the breaking of a truce, and assaults resulting in permanent blindness or debilitation of a limb. ${ }^{161}$ Vallerani examined separately cases which proceeded by accusation procedure (which was the most common criminal procedure in use at Perugia at this time) and inquisition procedure. He found that the peace played a major role in both. In the register of 1258 at Perugia of inquisitions in the court of the Podestà, comprising 80 cases, 50 cases, or 62.5 percent, ended in acquittals; 44 percent of these acquittals used peace agreements. Registers of successive years also showed frequent use of the peace accord. ${ }^{162}$ Sarah Blanshei also found peace accords in frequent

\footnotetext{
159 Sbriccoli, "Legislation, Justice, and Political Power," 50.

16o Vallerani, "Peace Accord and Trial," 178-180.

161 Vallerani, "Peace Accord and Trial," 183-186.

162 Vallerani, "Peace Accord and Trial," 196.
} 
use. In mid-fourteenth century Bologna, she found them involved in 29 percent of inquisitorial processes. ${ }^{163}$

The numbers at Reggio tell quite a different story. Overall at Reggio, only approximately nine percent of the extant trials include the use of a peace agreement. Where Vallerani found peace agreements in use for the worst offenses - including murder and rape — at Reggio, these agreements are found almost exclusively in assault cases of varying severity. Of a sample of 71 cases where the trial record records a peace between the parties, all but three were cases of assaults or quarrels that resulted in assaults. The remaining three cases include a charge of threatening assault, a charge of speaking injurious words, and a charge of theft. Peace agreements in homicide cases were necessarily transacted long after the crime was committed, because at Reggio such an agreement could only be concluded after the culprit had been banned from the commune for at least a year. Condemnation records do occasionally note the cancellation of a homicide ban, giving as one of many circumstances of its cancellation the pax. I have found no examples of the use of the peace agreement for other crimes in Reggio's criminal court. The use of peace agreements in lesser assault cases shows that while they could be used in serious cases to limit sources of vendetta, they were probably also used simply to "keep the peace" and to keep smaller altercations from escalating. Peacemaking did not end criminal proceedings and it did not confer absolution, but it could further mitigate a penalty after a confession. A 1386 decree from the Visconti allows the reduction of penalties by a quarter for a confession, and by another quarter if a peace is made. ${ }^{164}$ This was also true in Bologna, where peace agreements were used largely for their value in reducing penalties, rather than as tools of reconciliation. ${ }^{165}$

There may have been additional expenses involved in creating a formal peace, though our records at Reggio are silent on this issue. However, in Siena, the total costs for registering the peace, dismissing the inquest, and paying the notary amounted to a little less than one Sienese pound. ${ }^{166}$ At Milan, a peace agreement was necessary for a person to return from a ban imposed for a violent offense, ${ }^{167}$ and this appears to be the case also at Reggio.

Peace agreements found their way into criminal proceedings in a variety of ways. Instrumenta pacis could be drawn up outside the court and presented

163 Blanshei, "Cambiamenti e continuità nella procedura penale a Bologna," (forthcoming).

164 ASRe, Comune, Registri dei decreti e lettere, reg. 1385-1425, December 8, 1386.

165 Blanshei, “Cambiamenti e continuità nella procedura penale a Bologna," (forthcoming).

166 Kumhera, "Promoting Peace in Medieval Siena," 337

167 Verga, "Le sentenze criminali dei podestà milanesi," 123. 
before the judge as evidence. In a 1391 case, Antonius de Cereto was accused of assaulting another Antonius also known as Ughinus, and he hired Guido de Bebio, a local notary, to act as his procurator in the matter. Guido de Bebio appeared before the judge and "for the defense of the said Antonius produced an instrumentum pacis made with the said Antonius de Carcana, drawn up and written by Jacobinus de Burano, notary ..." ${ }^{168}$ The notary who acted as an advocate for the defendant did not draw up the act.

Sometimes these agreements were made orally outside the court, and then the accused had to present two witnesses to swear to the existence of the agreement. In 1397, a certain Rizardus was accused of robbing Dominicus de Barsasina. The complaint came to the court through a querela made by Dominicus which alleged that Rizardus took by force (per vim) property estimated at the value of 28 soldi. Rizardus confessed to the robbery, but claimed that he had made restoration to Dominicus for the value of the property and that he had made peace with him before witnesses. ${ }^{169}$ Two witnesses testified that they witnessed the peace agreement, which was transacted before Guilelmus de Lista, the captain of the city of Reggio. A marginal note indicates that in May of that year, Rizardus was condemned to pay six pounds imperial. The penalty was likely mitigated because of the peace made between the two men, but the peace agreement neither ended the proceeding nor prevented a condemnation.

Often at Reggio, these agreements were drawn up and signed in the camera of the criminal judge. (This common method of transacting a peace was the preferred procedure at Milan as well. ${ }^{170}$ ) A 1397 document records a peace made between Johannes de Placentia and Dominica de Tarasconibus, on the occasion of a fight between them. In this document, Johannes "made peace, remission and absolution" with Dominica, and Dominica likewise forgave: "every other injury, strike, and affront" perpetrated against her:

In the name of Christ, Amen... Johannes de Placentia, an inhabitant of the city of Reggio of the neighborhood of San Prospero de Castello, the

168 ASRe, Giudiziario, Libri delle denunzie, December 20, 1391, vol. 14, fols. 42r-44v: “... ad defensionem dicti Antonii produxit instrumentum pacis facere cum dicto Antonio de Carcana rogatum et scriptum per Jacobinum de Burano, notarium ..."

169 ASRe, Giudiziario, Libri delle denunzie, February 26, 1397, vol. 16, fols. 71r-72v: "[Rizaradus] ipsas omnes res eidem Dominico restituit et redidit et cum ipso et ab ipso Dominico pacem pacem remissionem et quietatum habuit et habet de predicto et cetere. Et quod paci et remissione sibi facte per eum inter fuerunt testes."

170 Verga, “Le sentenze criminali dei podestà milanesi," 121-122. 
above-mentioned struck and offended party, spontaneously, freely, and from certain knowledge made peace, remission, and absolution with the above-written Dominica de Tarasconibus of Borgo San Donino, an inhabitant of the city of Reggio in the said neighborhood... concerning the above-mentioned hits made against him by the above-written Dominica, and generally concerning each and every other injury, strike, and affront made, said, and inflicted by the said Johannes against the said Dominica, et cetera, the said parties promising to each other in turn and especially the said Johannes to her... to have, hold, and perpetually observe [the peace] by his own obligation and the obligation of all his goods, and under the penalty of 10 pounds R.L. imperial payable by the party who does not observe it. ${ }^{171}$

The agreement was drawn up by Petrus de Mutina with two other notaries as witnesses, in the camera of the judge. Dominica used this agreement to mitigate her penalty, presenting the document to the criminal judge:

On the same day. The above-mentioned Dominica, inquisita, to make her defense concerning the aforementioned matters, produced before the Lord Vicar the above-mentioned instrument of peace, so that she might rejoice in the benefit of peace according to the form of the decretals of our lord, et cetera. ${ }^{172}$

171 ASRe, Giudiziario, Libri delle denunzie, May 4, 1397, vol. 16, fol. 86r-v: "In Christi nomine Amen ... Johannes de Placentia habitator civitatis Regii vicinae Sancti Prosperi de Castello superius percussus et offensus sponte libere et ex certa scientia fecit pacem remissionem et absolutum superscripte Dominighine de Tarasconibus de Borgo Sancti Donini habitatori civitatis Regii in dicta vicina ibidem presenti de percussione superscripta eidem facta per superscriptam Dominighinam et generaliter de omnibus et singulis aliis inuriis percussionibus et contumellis sibi per dictam Dominighinam quomodolibet factis dictis et illatis. Et conversso [sic] dicta Dominighina pacem facit et remissionem generalem dicto Johanni de omnibus iniuriis questionis contumellis eidem Dominighine per dictum Johannem factis dictis et quomodolibet illatis et cetera, promittentes [dictam pacem formatum scripsit et delevit manuscriptus] dicte partes sibi ad invicem et specialiter dictus Johannes sibi ad praedictam ratam et formam habere tenere et perpetuo observare sub obligatione sui et omnium suorum bonorum et sub pena librarum $\mathrm{x}$ imperialium applicando parati observando et aufferendo a parte non observasit et cetera ..."

172 ASRe, Giudiziario, Libri delle denunzie, May 4, 1397, vol. 16, fol. 86r-v: "Die dicta. Superscripta Dominighina inquixita ad omnem ipsius deffensionem faciendo de predictis produxit coram superscripto domini vicario superscriptum instrumentum pacis ut gaudeat beneficio pacie secundum formam decretorum domini nostri et cetera." 
The "benefit of peace" was presumably the mitigation of her penalty. Dominica was still fined to pay the substantial penalty of twenty five pounds imperial for her crime.

The breaking of a peace agreement was a very serious matter. The statutes placed in perpetual ban those who broke the peace, whether it was a peace or truce made by the Podestà, or whether it was another kind of concord agreement, presumably including these instrumenta pacis. The ban could be lifted only at the will of the person with whom the peace had originally been made, or at the will of that person's heirs (voluntate eius vel heredis eius cui pax vel tregua facta fuerit. $)^{173}$ The $1335 / 71$ and 1392 redactions are identical, but the 1411 redaction recognized more distinctions and imposed additional pecuniary penalties in addition to the ban. Those who broke the peace by harming their enemies in persona, in addition to the ban and in addition to whatever fines their actions would merit on their own, also endured an additional 100 pound fine, of which half went to the offended party and the other half to the city. If the peace were broken by the destruction of the enemy's property, that additional fine was reduced to 50 pounds, payable half to the city and half to the offended party. ${ }^{174}$

Shona Kelly Wray found that in Bologna, the use of peace agreements primarily fell to the elite. ${ }^{175}$ In contrast, Andrea Zorzi found in Florence that these notarial instrumenta pacis were used by a great variety of social classes. ${ }^{176}$ Katherine Jansen's study of notarial peace agreements from 1257-1343 in Florence also found them employed by a people with a wide range of backgrounds, and used to resolve a wide variety of disputes. ${ }^{177}$ At Reggio, we find people from all walks of life using peace agreements, and not always in the form of a notarial document or public instrument. Particularly among the lower classes, peace agreements were sometimes transacted orally in front of the judge instead of with a public instrument drawn up by a notary. This oral peace avoided the fee of a private notarial instrument, but still served its function before the court. For example, in 1398, Petrus de Alamania, a German

173 ASRe, Comune, Statuti del 1335/1371, fol. 37r, and ASRe, Comune, Statuti del, fol. 156r, which are identical.

174 BSR, Statuti, ms. 77, fols. 6or-v.

175 Shona Kelly Wray, "Instruments of Concord: Making Peace and Settling Disputes through a Notary in the City and contado of late medieval Bologna," in Journal of Social History: Societies and Cultures 42 (2009): 735 .

176 Zorzi, "Legitimation and Legal Sanction," 34.

177 Katherine Jansen, "Pro Bono Pacis: Crime, Conflict, and Dispute Resolution. The Evidence of Notarial Peace Contracts in Late Medieval Florence," in Speculum 88 (2013): 432. 
scribe (scriptor), struck Anna de Flandria, a prostitute, in the face. The two appeared before the judge and made peace:

In the name of Christ, Amen ... Anna de Flandria, a prostitute, appearing before the distinguished and wise man Lord Gastarino de Grassis de Castronovo, publicly licensed in the civil law, honorable Vicar and Criminal Judge of the Lord Podestà of the city and district of Reggio, made and makes peace, concord, remission, and peace with Petrus de Alamania, scribe, present and receiving [it] ...

The instrumentum pacis was recorded in the trial record. It inventoried Anna's injuries, recording the damage done to her eye, that it was made "bruised and black." The document goes on to say that Anna appeared at the court

saying and protesting that the said peace and its benefit should give relief to the said Petrus in the condemnation to be made concerning this Petrus by the office of the aforementioned Lord Podestà, concerning which an inquiry was made against the said Petrus, promising to hold the said peace firm and strong, perpetually under the penalty of ten gold florins... and the obligation of all his goods, present and future.

Given in the city of Reggio in the palace of the commune of Reggio, with the Lord Tomaxius de Canonicha de Canoniis, a judge of the commune of the aforementioned Lord Podestà, and Nicolino de Lucha, the herald of the commune of Reggio, and others, named and brought forward as witnesses. ${ }^{178}$

178 ASRe, Giudiziario, Libri delle denunzie, June 17, 1398, vol. 18, fols. 1or-11v: "In nomine Christi amen. Anno circumxionis eiusdem milliotricento nonageximo octavio indictione sexta die $[\ldots]$ mensis Iulii Anna de Flandria meretrix coram egregio et sapiente viro in iure civili publice licentiato domino Gasparino de Grassis de Castronovo honorabile vicario et iudice malleficorum domini potestis civitatis et districtus Regii constituta fecit et facit pacem concordiam remissionem et quietationem Petro de Lamania [sic] scriptori presenti et recipiente de omnibus iniuriis sibi per dictum Petrum illatis et maxime de una percussione facta cum pugillo per dictum Petrum super facie ipsius Anne sine sanguine ita et quod fecit eidem oculum lundum et nigrum dicens et protestens predictam pacem et beneficium eiusdem debere opitulari predicto Petro in condempnatione fienda de ipso Petro per officium prefacti domini potestas de eo quod inquiritur contra ipsum Petrum promittens predictem pacem firmam et ratam habere perpetuo sub pena florenos decem auri et reffectione $\mathrm{d}[. .$.$] et ex parte litis et extra et obligationum suorum bono-$ rum presentium et futurum. Actum in civitate Regii in pallatio comunis Regii presentibus 
This contract specifically stated the reason for the peacemaking as the reduction of the penalty of the assault for which Petrus was charged.

The use of peace agreements by persons of lower social status, like prostitutes and mercenaries, was not uncommon at Reggio. In 1387, Marguerite de Alamania, also a prostitute, was beaten by Anex Calimber, a German mercenary in the city of Reggio. Anex used a wooden bastone to hit her in the head, causing an effusion of blood. Anex appeared in court and confessed to the charges. On the same day,

Margarita de Alamania, the offended party above, in the presence of the above-written Lords Podestà and Judge, made peace and remission with the said Anex, a hired soldier, concerning the above written strike made against her by the said Annex and concerning which [strike] an inquisition was made against him, et cetera. ${ }^{179}$

Anex was condemned to pay 12 pounds and six soldi $R . L$.

Peacemaking was used by people of every social standing, both men and women, from those designated as dominus or filius domini, to people of low social standing, including servants, prostitutes, and stipendiarii. This might imply that the motivation for these agreements was the mitigation of the penalty, and probably often enough there might have been some extra-legal incentives added to encourage the victim's participation in the peace agreement. This may also serve to underscore Zorzi's observation that vendetta and retribution in medieval society were not the sole province of the elite. ${ }^{180}$

In only one surviving case where a peace agreement was introduced was the defendant absolved, and it seems clear that he was absolved not because he made peace with his victim but because he presented the court with an acceptable reason for assaulting her. In a process dated January 10, 1396, the judge proceeded against Cataneus de Mediolano, a knight (cavalarium), and two of his servants, Antonius de Mediolano and Filipa de Barleta, because

domino Tomaxio de Canonicha de canoniis iudice conumis superscripti domini potestati et Nicolino de Lucha nuncio comunis Regii testibus nominatis et rogatis et aliis."

179 ASRe, Giudiziario, Libri delle denunzie, April 8, 1387, vol. 8, fol. 87r-v: "Margarita de Alamania superius offensa existens in presentia superscriptorum dominorum potestas et iudicis fecit pacem et remissionem dicto Anex stipendiarius de superscripta percuxione sibi per dictum Annex [sic] illata et de qua superius inquiritur contra ipsum Annem [sic] et cetera."

180 Zorzi, "Legitimation and Legal Sanction," 34. 
while the aforementioned Antonius and Filipa argued together with words, this Filipa, with an angry heart and in a wicked manner, took a stone in her hands and threw it at the said Antonius and hit him in the face, one strike without [drawing] blood. And then the said Antonius, with an angry heart and in a wicked manner and way,... took another stone in his hands and holding it in his hand he hit the said Filipa with the said stone on the face two times: one strike below the eye and the other on the brow of the said Filipa, both with great bruising, and another strike in the head from behind Filipa, without blood. After a little while, the said Cataneus arrived and took the said Filipa by the hair and scratched her and threw her on the ground and with his feet and his fists he stuck and beat her thus lying there. ${ }^{181}$

Cataneus and Filipa appeared together before the judge on January 14; Filipa confessed to the charges against her, while Cataneus confessed that he had scratched, hit and beaten her, but he did it because he was trying to correct her, and make her return home, and the statutes gave him this right. ${ }^{182}$ Cataneus himself stood as the fideiussor for Filipa, but no one pledged surety for Cataneus, which is very unusual unless the proceedings were terminated against him as soon as he produced the statutes. On the same day, Filipa appeared to make peace with Cataneus, "saying that he did these things to her for the purpose of correcting her, and [he did them] with a good heart and for

181 ASRe, Giudiziario, Libri delle denunzie, January 10, 1396, vol. 15, fols. 2or-21v: “... quod dum predicti Antonius et Filipa simul verbis contenderent ipsa Filipa animo irato malo [modo] et ordine ceperit unum lapidem in manibus et ipsum lapidem contra dictum Antonium proiecit et ipsum percussit super vultu una percussionem sine sanguine. Et tunc dictus Antonius animo irato malo modo et ordine quibus supra cepit unum allium lapidem in manibus et cum dicto lapide tenendo eum in manu percussit dictam Filipam super vultu duabus percussionibus una super oculum et allia super frontem dicte Filipe ambabus cum magna smaxitura et una allia in capite de retro de dicte Filipe sine sanguine postea stando modicum supervenit dictus Cataneus et dictam Filipam cepit per capillos et ipsam sgarmigliavit et proiecit in terram et cum pedibus et pugilis ipsam sic prostractam [sic] percussit et verberavit."

182 ASRe, Giudiziario, Libri delle denunzie, January 10, 1396, vol. 15, fol. 20v: "Dictus vero Cataneus dixit et sponte confessus fuit se sgarmigliasse percusisse et verberasse dictam filipam eius famulam et pediustram prout in dicta inquixitione continentur sed ipsam sgarmigliavit percussit et verberavit animo et intentione ipsam corigendi et ipsam faciendi redire domum. Dicens et protestans idem Cataneus ad deffensionem suam sibi licuisse et licitum fuisse predicta facere vigore statutorum comunis Regii que quidem statuta producit in alegat in ea parte et partibus specialiter in qua et quibus faciunt pro iuris et defensione sui." 
her own good..."183 Cataneus produced the written instrumentum pacis in his own defense. It is not entirely clear why the peace agreement was necessary at all. Filipa was charged with assaulting Antonius, not Cataneus; she made a separate peace agreement with Antonius that mitigated her own penalty, and Cataneus was absolved and so incurred no penalty at all. It is a curious case, but it demonstrates that these peace agreements served a multiplicity of purposes and crossed class and gender boundaries.

There were many reasons why a culprit might seek a peace agreement, not the least of which was a possibility for a reduced sentence. But why would a victim choose to enter into a peace agreement? Victims sometimes needed encouragement, which could involve their friends and neighbors. When Bartolinus de Placentia struck Luchinus de Placentia with a rock, drawing blood, the neighborhood immediately began to talk. As Luchinus lay bleeding, a prostitute ran to fetch help, asking a certain Jacobus to fetch a doctor. Jacobus ran to Magister Maxotus de Bebio, a surgeon, and as the men walked back to Luchinus, Jacobus told him that he heard it was Bartolinus who had committed the assault and he thought it would be better if Maxotus could convince the men to make peace, and the matter went no further. Maxotus replied confidently that he would get involved, and he did not doubt they would bring the matter to him. ${ }^{184}$ Only a partial record survives, so we do not know the

183 ASRe, Giudiziario, Libri delle denunzie, January 10, 1396, vol. 15, fols. 20v-21r. The peace was sworn before the judge. "Superscripta Filipa constituta coram superscripto Domino Vicario Iudice Malleficorum fecit pacem remissionem et absolutionem perpetuam et perhennem dicto Cataneo presenti et recipiendi de omni sgarmigliatione percussione decapilatione iniuria et contumellia sibi factis illatis et datis per idem $\mathrm{Ca}[\mathrm{ta}]$ neum et specialiter de omni eo quod sibi fecit idem Cataneus loco et tempori in dicta inquixitione contenta dicens quod illud sibi facere causa ipsam corigendi et bono animo et pro suo bono et utili promittens per se et suos heredes dictam pacem et remissionem dicto Cataneo presenti $[\ldots]$ sub pena libras decem et obligationem sui et omnium suorum bonorum et cetera. Quam superscriptam pacem et remissionem dictus Cataneus produxit in continenti coram dicto Domino Vicario ad omnem suam defensionem faciendum de predictis."

184 ASRe, Giudiziario, Libri delle denunzie, November 11, 1403, vol. 20, fol. 136v. "Jacobus Tragnolus sartor... dixit... quod quedam meretrix, quam tenet dictus Luchinus de Placentia, accessit ad ipsum testem dicendo quod reperiat eidem unum medicum qui medicaret dictum Luchinum, qui fuerat percussus ... et tunc dictus testis ivit ad reperiendum Magistrum Maxotum de Bebio et eum duxit ad domum dicti Luchini, et in itinere dictus Magister Maxotus dixit cum dictum testem, 'Quis percussit dictum Luchinum?' Et dictus Jacobus respondit, 'Ego audivi a dicto Luchino quod fuit Bartolinus barberius de Placentia, et vere esset bonum antequam res procederetur ulterius quod faceretis eos facere pacem.' Et dictus Magister Maxotus respondit, 'Ego me intromitam et non dubito quod veniet michi factum.'” 
final outcome, but another witness said later that Maxotus did get involved, telling Luchinus that it would be better for him to make a peace accord with Bartolinus-not the least because then Bartolinus would pay his medical costs - but at least initially, Luchinus refused.

Certainly the possibility to put aside a dispute and end the possibility for vendetta played an important role in the victim's motivation to seek peace. There may also have been other motivations. Formal agreements of peace before a notary usually included a penalty for breaking the agreement, as did the statutes, but they did not involve exchanges of property or other incentives for making peace. Part of the difficulty with using peace agreements to reconstruct social reality is that the agreement itself was probably only the tip of the iceberg. Real peace negotiations probably involved more negotiation than the simple agreement recorded by the notaries or sworn before the judges would suggest. Any such negotiations would have resulted in private, oral agreements.

A rare glimpse of this sort of peace negotiation survives in a strange criminal investigation, which we have already discussed in Chapter Four (as it pertains to the history of torture). This document is worth revisiting here because of the unusual insight it offers into peace negotiations. We return to Antonius Raddi, accused of murdering a certain Daninus, a retainer of Guido da Fogliano. Guido had Antonius captured and held him in his castle at San Polo. There was no solid evidence for the crime, so Guido brought an official to the castle and hid him behind a curtain while Guido attempted to elicit a confession from Antonius. With the official hidden behind a curtain, Guido began a conversation with Antonius with the intention of eliciting a confession. He did so by negotiating a peace with him:

Guido went to Antonius Raddi. When Antonius saw Guido, he said to him, "Welcome," which Guido said, "I do not have any right to speak to you, who killed my man." Which Antonius began to deny, and to say that this was not at all true. Then Guido said, "How can you deny those things which Bartholameus Botus and Johannes de Lamotta said to me? But if you wish to take as your wife the daughter of Maffeus de Vecto, who is your enemy and my friend, and to make her a dowry of fifty-five gold florins, then you will still be my friend by making peace with Maffeus and his brother Andriolus. You see, if I cause you to be hanged, there is nothing [in it for me], and I will not be enriched at all." Then Anthonius said that he was prepared to make peace with the aforementioned men but he could not take his daughter in marriage as a wife, since he was already married; but he would make his nephew marry her. He could not 
provide such an ample dowry of 55 florins, but he would provide one of 25. Then Guido said that he wanted Antonius to kill one of his men who killed Daninus, which Antonius promised he would do; and then Antonius said to Guido that Bartolomeus Botus and Johannes de Lamota were those men who led Antonius to Daninus, and he said that it was true that he killed Daninus. And thus this witness heard from Antonius himself..."185

Had Guido been in earnest when negotiating this agreement, he would have been asserting the value of private justice ("You see, if I cause you to be hanged, there is nothing [in it for me], and I will not be enriched at all"), which clearly seemed reasonable to Antonius. And there was justice inside the agreement. The dowry of fifty-five gold florins corresponded to the amount of money that Antonius stole from the dead man. Vengeance would still be exacted against

185 ASRe, Giudiziario, Libri delle denunzie, September 10, 1397, vol. 17, fols. 8r-13r.: "Quod dum nobilis vir Guido de Folianno accesserit ad castrum Sancti Pauli ad Carolum de Guarcho lochum tenentem Capitanei episcopatus Parme et Regii super deveto de mense Augusti et diceret dicto Carolo ut faceret sibi ius de quodam Anthonio Raddi de Vidrianno quem habebat in carzeribus [sic] qui sibi interficerat unum ex suis hominibus. Qui Carolus respondit quod erat paratus ius facere si daret sibi probationes vel indicia propter que posset ipsum ponere ad torturam, qui Guido dixit 'Si vultis vos ponere in secreto itaque ipsum audire valeatis ego solus ibo ad ipsum et talles tenebo modos quod ipse erit confessus dictum delictum,' qui Carolum dixit quod multum contentebatur et se posuit retro una frascatam et ipse testis etiam se posuit prope dictum Carolum et dictus Guido accesserit ad dictum Antonium Raddi. Et dum dictus Antonius videret dictum Guidonem sibi dixit, 'Bene veneretis [sic],' qui Guido dixit, 'Ego non habeo ius aliquod tibi dicere qui interfecisti hominem meum,' qui Anthonius incepit negare et dicere quod minime erat verum, qui Guido tunc dixit, 'Quomodo potes tu negare quoniam Bartholameus Botus et Johannes de la Motta michi dixerunt? Sed si vis ducere in uxore filiam Maffei de Vecto qui est tuus inimicus et est amicus meus et facere sibi dotem de quinquaginta florenis auri, ut aduc [adhuc?] eris meus amichus faciendo pacem con dicto Maffeo et Andriolo fratri ipsius Maffei, quia si facerem te suspendi nec aliud esset et nichil essem lucratus,' qui Anthonius dixit quod erat paratus pacem facere cum predictis sed filiam ipsius capare non posset in uxorem quoniam erat uxoratus, sed faceret quod quidam eius nepos eam capaveret in uxorem, sed non posset tam amplam dotem facere, videlicet, de florenis quinquaginta quinque, sed faceret de vigintiquinque florenis. Qui etiam Guido dixit quod volebat quod interficeret unum ex illis hominibus qui interfuerunt morti dicti Danini, qui promixit sic facere, et tunc ipse Anthonius dixit dicto Guidoni quod Bartolomeus Botus et Johannes de la Mota fuerunt illi qui duxerunt ipsium Anthonium ad dictum Daninum et dixit quod verum est quod fuit morti dicti Danini et ita ipse testis audivit a dicto Anthonio praedicto..." 
one of the murderers. And a new bond would be made between allies and enemies, limiting the possibility of the vendetta.

It seems most unlikely that the highly formulaic peace agreements, sworn orally or made in writing, represent the negotiations that ultimately resulted in the instrumentum pacis. These documents do not record details of individual circumstance or motivation. While peace agreements must be considered in relation to their legal power in the criminal court, they must also be read with the understanding that they represent more complex negotiations that ended conflicts, made retribution for wrongs, and perhaps sometimes included provisions, such as Guido's requirement that Antonius kill another man, that were themselves illegal.

Peace agreements and confessions were the most common tools employed to mitigate penalties, but in rare cases, other agreements were used to avoid a conviction, such as agreements of marriage in rape cases. In two rape cases recorded at Reggio Emilia where the victims were children, the defendants were absolved because they agreed to dower and marry their victims. Trevor Dean observed that the difficulty of understanding the horrifying practice of betrothing a rape victim to her attacker "is because the modern crime of rape has shed all connection with abduction, and because 'normal' sexuality has become less violent."186 But this would not explain these cases of child rape, where the confusion between rape and abduction does not appear. A 1396 case illustrates this problem.

In 1396, Johannes Axerbi, a citizen of Reggio, was accused of raping a certain Johanna, a girl eight years old, and daughter of Domina Johanna de Lenco. The record states that Johanna was playing outside Johannes's door with some other children, when Johannes said to her, "Come into my house so I can give you some bread and wine." She entered the home, where immediately he threw her on the bed and raped her. She fought him, as the record says, "shouting and continually and bravely objecting to the violence he was doing to her," though he told her that if she cried out, he would throw her against the wall and cut out one of her eyes. ${ }^{187}$ Another rape that resulted in the betrothal of a child to her attacker was equally violent - at one point, the attacker threatened to feed her to his dogs if she cried out. ${ }^{188}$ Are these formulaic pieces of dialogue,

186 Trevor Dean, "Fathers and daughters: marriage laws and marriage disputes in Bologna and Italy, 1200-1500," in Marriage in Italy, 1300-1650, eds. Trevor Dean and K.J.P. Lowe, $88-89$.

187 ASRe, Giudiziario, Libri delle denunzie, November 26, 1387, vol. 9, fols. 61r-62r.

188 ASRe, Giudiziario, Sentenze e condanne, reg. 7, fols. 16v-17r: “... minabatur eidem Petre dicendo quod ipsam comedere faceret canibus suis tamen dicta Petra nolendo eidem 
as Vallerani noted, when he found that rapes continuously began with the attacker's admonishment: "I will kill you / I will cut off your nose, unless you are silent and permit me to do as I wish with your body"? 189 This is possible, and it is also possible that the age of the child is minimized by the complainant, and the entire accusation existed to force a marriage agreement. Certainly both these children were ultimately betrothed to their attackers. Yet we saw in the previous chapter, in the trial of Antonius de Albrixiis, when a judge became aware that witnesses to the crime were children, he wanted to judge their age with his own eyes. ${ }^{190}$ Many instances where sexual violence appears in the trial records may indeed be veiled references to elopement or abduction, but in these particular cases, the law and the mothers' insistence that it be applied to the rapists may be best understood as indicators of how difficult the children's lives might have been, had they remained shamed and unmarriageable. In both these cases, the agreement of marriage served to absolve the defendant from the charge of the rape of a child, which carried a mandatory death penalty.

\section{Signorial Participation in the Administration of Justice: Instruction, Cancellations, and Pardons}

The participation of the lords of Milan in quotidian matters of justice constituted an overarching layer of authority in the criminal courts. The Visconti lords of Reggio received queries from the Podestà as well as supplications from accused or condemned defendants, and were deeply entwined in the administration of justice. This participation was characteristic of northern Italian signorial regimes, and has been noted at Milan during the same period. ${ }^{191}$ Other studies have also revealed this sort of interaction between signorial lords and municipal courts under Gonzaga and Este leadership ${ }^{192}$ and during the reign of Taddeo Pepoli in Bologna. ${ }^{193}$

Petro ascentire sed semper resistendo et recusando non obstantibus minis predictis continue plorabat..."

189 Vallerani, "The Accusatory System in Action," 130.

190 ASRe, Giudiziario, Libri delle denunzie, fol. 3v: “...ex aspectu personarum suorum videntur etiam minores decem annorum, dictus Dominus Vicarius et Iudex Malleficorm pronunciavit et declaravit predictos Simonem et Simonem examinandos non esse super dicta inquisitione et contentis in ea."

191 Verga, "Le sentenze criminali dei podestà milanesi," 120-125.

192 Chambers and Dean, Clean Hands and Rough Justice, 83.

193 Vallerani, "The Petition to the Signore," 321-339. 
At Reggio, in addition to those decisions that are preserved in the Registri dei decreti, evidence of this participation is found in interlinear and marginal notes in trial records and books of sentences, and in some surviving decrees from the Milanese court. We find advice dispensed on specific cases, orders for the cancellation of proceedings, and granted absolutions (gratia). All these acts were typical in general of responses to petitions by signorial governments.

Many of the extant examples of this signorial participation date to the rule of Regina della Scala. The queries posed by the Podestà of Reggio are minute in their applicability and detail. An illustration of these referred cases and of signorial participation in the justice system at Reggio is provided by a degree of 1374 from Regina della Scala to the Podestà of Reggio. This decree addressed the larger problem of civil disorder caused by mercenaries, stipendiarii, who were housed at Reggio. Regina herself took an active role in attempting to control the disorder caused by the hired soldiers present at Reggio, and she wrote to the Podestà:

We have understood that certain men from our stipendiarii and provisionates staying at Reggio inflict damage and injuries upon our citizens of Reggio, in violating their women and in not making due payments for the rents of homes and property which they take for their own use. Whence we order you that you should immediately inform us about the aforesaid matters, and if you should discover that anyone from these stipendiarii or the aforementioned mercenaries has committed any illicit act, you should write to us, etc. ${ }^{194}$

The Podestà and his judges responded to this request by referring a wide variety of matters to Regina for her guidance. In response, Regina made proclamations on civil as well as criminal cases, and on situations that were likely to lead to conflict. She also concerned herself with cases that appear to deal with minutiae, including marriage difficulties and dowry problems. When a certain Guilelmus Copini, citizen of Reggio, complained that Mayninus de Mayneriis of Milan, an inhabitant of the city of Reggio,

194 ASRe, Comune, Registri dei decreti e lettere, reg. 1372-75, February 22, 1374: "Inteleximus quod certi ex stipendiarii et provisionatis nostris in Regio commorantibus dampna et iniurias inferunt civibus nostris Regii in eorum violando mulieres et non faciendo solutiones debitas pro pensionibus domorum et rerum quas acipiunt pro eorum usu quare mandamus vobis quatenus statim de predictis vos informetis et si reperitis aliquem ex stipendiariis vel provixionatis predictis aliquid illicitum comixisse ut prediximus ad nobis rescribatis et cetera." 
gave to this Guilelmus as a wife Placentina de Mantua, whom the said Mayninus before held as his lover (amaxia), and [he said] that the said Mayninus promised to Guilelmus twenty-five gold florins as a dowry for the said Placentina, and one robe of good cloth for Placentina's use; further, [he stated] that the said Guilelmus held the said Placentina as his wife in his home for eight months. And since afterward she left and went to stay with the said Mayninus, he does not wish to give her her dowry.

The Podesta had ordered a preliminary investigation:

Concerning these matters, we received the information of the aforementioned Deputy concerning the promise of a dowry, he had no faith nor information, and he found that the said Placentina, once separated from her said husband, went to stay at the castle of S. Paolo, where the brother of the said Mayninus was staying, and afterwards she returned with her said husband and stayed with the mother of the said Placentina, and he could not find other information.

Regina's decision was straightforward. She replied:

If the said Placentina wishes to go with her said husband, we are content that she goes. 195

No other information about the case is given; apparently the wronged husband had made a petition with the court of the Podestà to require his wife to return

195 ASRe, Comune, Registri dei decreti e lettere, reg. 1372-75, February 22, 1374: "Guilelmus Copini Barberii civis Regii dixit per sacromentum quod Mayninus de Mayneriis de Mediolano habitator civitate Regii dedit eidem Guilelmo in uxorem Placentinam de Mantua quam dictus Mayninus ante tenebat pro sua amaxia et quod dictus Mayninus promixit ipsi Guilelmo pro dote dicte Placentine florenos xxv auri et unam robam ab uxu dicte Placentine de bono panno et quod ipse Guilelmus tenuit dictam Placentinam pro sua uxore in domo sua pro octo menses. Et quod postea recesit et ivit ad standum cum dicto Mayninum, quam dare non vult nec dare dotem. Super quibus dicti deputati informationem recipientes de promissione dotis nullam fidem habuerit nec informationem et reperiverit [sic] quod dicta Placentina quoddam semel discessit a dicto suo viro et ivit ad standam ad castrum Sancti Pauli in quo morabatur frater dicti Maynini et posta reversa fuit cum dicto suo viro, et moratur cum matre ipsius Placentine aliam informationem reperire non potuerit. [Responsio ut super] Si dicta Placentina vult ire cum dicto suo marito, contentamus quod vadat." 
or to allow him to keep her dowry if she did not, and the Podestà referred the case in accordance with Regina's order because the men were mercenaries.

Other cases clearly involve criminal matters and show that the Podestà sought approval for certain cases to proceed even after a complaint or querela had been made with his officials. For example, one case considers what appears to be a straightforward assault:

Senexia, wife of Azalirius de Saviola, a Reggian citizen, complained that around the month of this January at the time of night, Cataldus de Pullia, a hired soldier, with a certain comrade, entered the home of the said Senexia and went to her bed and hit her with a stone which he was holding in his hands on the head of this Senexia, many strikes, with a great effusion of blood, and he hit her in many parts of her person.

The incident may have been referred to Regina because it involved a hired soldier, but in spite of her demand to be informed of cases involving these men, Regina herself seemed perplexed by the court's inaction, irritably responding,

We wonder why no process is made concerning the aforesaid [and we] desire that the law should be rendered concerning this [crime] by our Podestà of Reggio. ${ }^{196}$

Other incidents referred to Regina's decision probably aimed more at settling disputes between the municipal officials themselves than in resolving particular cases, for example, when Nicholaus Pichioni, a cobbler and a citizen of Reggio, made a complaint that Johannes de Cremona, a hired soldier, "threatened him many times that he would kill him." Regina responded, "The city captain should provide that our stipendiarii do not inflict injuries or threats upon our citizens of Reggio."197

It is perhaps not too much to say that sometimes, the signorial court shouldered the function of a consilium sapientis, directing the judge how to proceed

196 ASRe, Comune, Registri dei decreti e lettere, reg. 1372-75, February 22, 1374: "Responsio ut super. Miramus quare non est factus processus de predictis volentes quod ius super hoc fiat per potestatem nostrem Regii."

197 ASRe, Comune, Registri dei decreti e lettere, reg. 1372-75, February 22, 1374: "Nicholaus Pichioni calzolarus civis Regii conquestus est de Johanne de Cremona provixionato quod minatus fuit eidem pluries de ipsum occidendo. Responsio ut super, capitaneus taliter provideat quod stipendiarii nostri non inferant iniurias nec minas civibus nostris Regii." 
in ambiguous matters. ${ }^{198}$ In 1387, Agnexina, daughter of Cupinus, was accused of killing a small child. In the course of an argument with the child's mother, she grabbed the child by the arm, lifted her and threw her to the ground, from which injuries the little girl died. ${ }^{199}$ On September 8, Agnexina confessed, and she was granted a term of eight days to make her defense, instead of the more usual ten days. On September 24, Agnexina's father, seeking to defend her, hired a notary to draw up a sworn statement in which the father of the child declared that the child died not because of Agnexina's actions, but because she had always been gravely ill. In this document, the child's father also testified to the friendship that had existed always between himself and his family, and Cupinus and Agnexina, denying that the familes had ever had enmity. Johanna, the mother of the little girl, testified similarly that the child had been ill. But still Agnexina remained in jail. On the 17th of October, a letter from Milan was presented to the Podestà, ordering him to give consideration to the document, and that if the father and mother both testified to the cause of death in the instrument, then Agnexina should be released. This release was ordered a full twelve days later, on October 29 th.

There were other benefits to the arrangement for the foreign rectors. In criminal cases, the consilia sapientis were seldom used. Cases involving complicated scenarios or conflicting jurisdictions were generally not referred to jurists for final decisions. Instead the Podestà could rely upon the guidance of Milan, which had the added benefit of moving difficult decisions out of their hands-important, because they faced syndication at the end of their terms. Consilia sapientis protected judges by reducing the judge's personal liability in the case. ${ }^{200}$ This was also the benefit of these requests for signorial guidance in court matters. And they emphasized too the nature of power in the Visconti dominions. Signorial authority, with its plenitudo potestatis, rendered a final decision that lay outside the hands of the judge, at the highest level of authority. This was absolutely in line with the theory of justice that underlay Visconti reforms during the late fourteenth century: if Barnabò and Galeazzo believed that justice was best served by abbreviating procedures and limiting the role of

198 These responses had an entirely different form from the sic-et-contra form common to consilia, by which the jurist established the authority of his opinion. Kirshner identified four primary bases of the authority of the consilium sapientis in civil (and sometimes criminal) courts - professional expertise, impartiality, the dignity and sacred character of the legal profession, and rules of judicial accountability which allowed for unmotivated decisions. See Kirshner, Consilia as Authority, 109-125.

199 ASRe, Giudiziario, Libri delle denunzie, September 8, 1387, vol. 9, fols. 49v-5or.

200 Kirshner, "Consilia as Authority." 
lawyers in the courts, and Giangaleazzo and his successors "proceeded to give further encouragement to a system in which justice was grounded on their ability to overturn laws and rights," ${ }^{201}$ then this direct, case-by-case intervention in justice aligned very well with these views.

\section{Gratia and the Cancellation of Proceedings}

There was no appeal process for criminal sentences. However, cancellations of ongoing trials and pardons from convictions could be obtained directly from the court at Milan. In fact, Barnabò and Regina chose to increase access to the process at Reggio by providing a place in the city where petitioners could leave their requests, ${ }^{202}$ and perhaps for this reason, the petitioners in these cases were not all of one social class or profession, though they were often hired soldiers, stipendiarii. This was a useful tool of recourse for people from all walks of life. This interference with the activity of the criminal court emphasized the power of the Lords of Milan, and during the reign of Barnabò and Regina, who firmly maintained the right to operate above and outside the law of the land, such petitions were widely used. But the practice posed vast legal questions, dealing as they did with singular situations, ${ }^{203}$ and sometimes imposing, sometimes setting aside municipal norms. These suppliche or acts of gratia represent a practice that was growing but still largely unsystemized in the fourteenth century. At Reggio, the evidence for the practice takes the form both of records of the decrees, and marginal notations or interlinear notes in the Libri delle denunzie or in the Sentenze e condanne. The evidence is not systematic, and a quantification of the frequency of the practice is impossible. Indeed these orders could have halted many trials before they began, as they often include the caveat that if the proceedings have already been written in the books of trials, they should be cancelled, implying that the order could reach the court before those records were made.

Increasing accessibility to the process of appeal spoke volumes about the nature of power in Visconti Reggio. Here was a way that the court's decisions could be questioned or even set aside; the petitions operated not as appealsthe cases were not reheard - but as kind acts made by a powerful and benevolent lord. The petitions at Reggio, as was normal for the genre, ${ }^{204}$ emphasized

\footnotetext{
201 Black, Absolutism in Renaissance Milan, 118.

202 Black, Absolutism in Renaissance Milan, 117.

203 Vallerani, "The Petition to the Signore," 347.

204 Vallerani, "The Petition to the Signore," 306.
} 
the grace and magnanimity of the lord of Milan in his (or her) responses to these petitions. Even after the fall of Visconti control in Reggio, the new lord, the condottiero Ottobuono Terzi, continued the practice, though less frequently, and with great concern about the possibility of fraud: he was very concerned that letters of gratia were authentic, and he ordered the Podestà to verify the presence of his seal. ${ }^{205}$

In 1373, Rizardus de Antonius, an English mercenary, murdered one of his countrymen, Schielar de Anglia. ${ }^{206}$ A contingent of these mercenaries, probably a fortune company, was housed in Reggio. A marginal note tells us that the proceeding was cancelled by an order from Milan, which read:

Attending to the supplication of Lord Conrad de Rodesten, Lucius Sparaverius, and others of our German and English mercenaries living in Reggio, we order you that you should take no new action against Rizardius Anton, an Englishman whom you have detained for the reason that he killed a certain servant of his, but rather you should freely release him from jail, annulling and revoking every process made against him on the aforesaid occasion. ${ }^{207}$

It is possible that the mercenary capitans interfered because they wished to exercise their own jurisdiction over these men, a jurisdiction that would later fall into the hands of the captain of the city. These men made a supplication to Milan on Rizardius's behalf, causing the cancellation of the inquisition made against him. Whether he was held accountable for the murder by another court or by his superiors is unknown, but it seems unlikely, as he was denounced again to the criminal judge a few months later. On April 5, 1374, Rizardius was cited by the court to answer charges that he assaulted an inhabitant of the city of Reggio, beating him in the head and body with a wooden club. Rizardius was contumacious and placed under ban. ${ }^{208}$ Jurisdiction may have underscored many of these contested rulings. In the same way, as was discussed in Chapter 2,

\footnotetext{
205 Gamberini, "Un condottiero," 296 n. 63.

206 ASRe, Giudiziario, Libri delle denunzie, December 13, 1373, vol. 1, fol. 47r-v.

207 ASRe, Giudiziario, Libri delle denunzie, December 13, 1373, vol. 1, fol. 47r: "Attententes [sic] suplicationi domini Conradi de Rodesten Lucii Sparaverii et aliorium nostrum provixatorum Teotonicorum et Anglicorum existentium in Regio mandamus tibi quatenus contra Rizardium Anton anglicum quem detentum habes causa quia interfecit quemdam eius familiarem nullam novitatem facias sed ipsum a carceribus libere relaxes tolendo et revocando omnem processum contra ipsum factum occaxione predicta."
}

208 ASRe, Giudiziario, Libri delle denunzie, April 5, 1374, vol. 1, fols. 91r-92v. 
the heirs of Gabriotto da Canossa petitioned Milan to stop a proceeding against a certain Marcocius who was accused of murdering his wife, because they wanted to require the city to respect their claims of jurisdiction. ${ }^{209}$

Ambiguous situations could be referred to the lord for an opinion, much as a judge might use a consilium sapientis. For example, in 1378, Nicholaus de Cornazatio, a servant of the Capitano della Città, was accused of murdering Bartholina, daughter of Zacharius, because

While the said Nicholaus, with his said horse, which he was making to run, this Nicholaus with the said horse pushed Baratholina, daughter of the deceased Zacharius, furrier, who was crossing the public street, in such a way that she fell to the ground, on account of which the aforesaid horse placed his feet upon the head of the said Bartholina, in such a way that he caused three wounds to Bartholina in her head, with an effusion of blood, from which strikes and wounds the said Bartholina, after some interval of time, was and is dead. ${ }^{210}$

Nicholaus was charged and cited, which citation he ignored; he was then placed under ban in the amount of 1,000 pounds R.L., the amount of a ban used for murders. In December of that year the case against him was cancelled because of an order from Regina della Scala. The notary who cancelled the case recorded the order in the margin:

We order you that you should in no way proceed against Nicholaus de Cornazano, a servant of Nicholaus Tereius, the captain of our Reggio, on the occasion of a death of a certain woman. And if you have begun any process, you should cause it to be freely cancelled, since no one can be forewarned. ${ }^{211}$

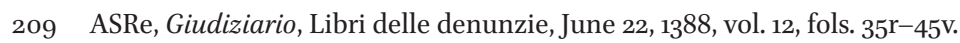

210 ASRe, Giudiziario, Libri delle denunzie, vol. 4, fol. 135r: “... dum dictus Nicolaus cum dicto equo quem curere faciebat ipse Nicolaus cum dicto equo taliter spinxit Baratholinam filiam condam Zacharie pilizarii per stratam publicam transeuntem quod eam cadere fecit in terram ob quem casum equus predictus posuit pedes super capite dicte Bartholine sic et taliter quod fecit ipsi Baratholine tria vulnera in capite cum sanguinis effuxione. Ex quibus percussionibus vulneribus dicta Bartholina per aliquod spatium temporis mortua fuit et est."

211 ASRe, Giudiziario, Libri delle denunzie, November 15, 1378 and following days, vol. 4, fols. 135 r-136v: "Mandamus tibi quatenus contra Nicolaum de Cornazano familiarem Nicholay Tereii capitanei nostri Regii occaxione mortis eiusdam femine nullatenus 
These orders followed supplications made by the accused for a pardon, or gratia, who usually remained contumacious until the request was answered. Gratia was conferred after a sentence was handed down against the defendant. As at Milan, gratia conferred complete and unconditional absolution. ${ }^{212}$

Few of the supplications themselves survive. One extant example dates to 1386, and coincidentally, involves another horse. A certain Minus was accused of murdering a German mercenary, Annes de Alamania, by running him down with his horse. ${ }^{213}$ Minus was convicted and sentenced to death; he was contumacious, and placed under ban for 1,00o pounds. His condemnation survives in the register of condemnations from 1386 . The sentence itself was cancelled (indicated by hatch-marks) and a marginal note dated June 3, 1395 tells that a supplication was received and granted. The notary recorded the text of the supplication within the marginal note, in which the convicted man claimed that he had accidentally killed Annes "not led by wickedness, but innocently running with a horse through the street..."214 and that the death was an accident, which occurred "not wickedly or voluntarily, but by chance..." ${ }^{215}$ Minus also stated that he had made peace with the brother of the dead man. In this way, his sentence was cancelled and the ban against him was lifted, albeit nine years after the fact. Minus was contumacious, and apparently never attempted to defend himself to the judge of the Podestà. The truthfulness of his claim, as in the case of all claims made in supplication, is of course open to question: as a judge in Ferrara many years later would remark to his duke, "everyone lies in petitioning in order to obtain your Excellency's pardon."216

Ettore Verga found that gratia could be conferred in the case of a violent crime only when a peace agreement had been completed between the offender and the victim. ${ }^{217}$ The desire for the formal peace may explain the frequent long delays between conviction and the conferral of gratia - this was not a problem specific to Reggio, but was the case in Milan itself, and was also a pattern in mid-fifteenth century Mantua. Whether these long delays reflected

procedas. Et si quem processum fecisti illum incontinenti libere facias canzelari quoniam etiam infortuniis casibus nemo sibi precavere potest."

212 Verga, "Le sentenze criminali dei podestà milanesi," 123.

213 ASRe, Giudiziario, Libri delle denunzie, March 23, 1386, vol. 7, fols. 43r-44v.

214 ASRe, Giudiziario, Sentenze e condanne, reg. 1, fol. 4r: “... nulla malignitate ductus sed innocenter currens cum uno equo per platea..."

215 ASRe, Giudiziario, Sentenze e condanne, reg. 1, fol. 4r, "non dolose non voluntarie sed casu fortunito..."

216 Quoted in Chambers and Dean, Clean Hands and Rough Justice, 34.

217 Verga, "Le sentenze criminali dei podestà milanesi," 123-24, cf. Pertile, Storia del diritto penale $\mathrm{V}, 180,188$. 
difficulties in arranging the peace agreement, resulted from long imprisonments while the question hanged with the ducal court, ${ }^{218}$ or whether applicants were unlikely to successfully petition until they had suffered some of the punishment a ban could offer, it is not possible to know.

Punishments in the court were sometimes intended as deterrents, as in the case of public executions, but these public displays of power were rare. Although the court used inquisitorial procedure almost exclusively, which at least in theory was designed to facilitate the punishment of crime, in fact, the court still acted in a way to maximize conflict resolution. Rewarding the use of the instrumenta pacis is one example of this. Another is in the use of capital and corporal sentences. Though the court at Reggio did not sentence murderers to a ban directly (they incurred this sentence only through their contumacy), the contumacy rate of those accused of murder was so high that it must have been expected, and one can imagine that contumacy in this sense was not only a strategy for the defendant, as was discussed in the previous chapter, but was also a strategy for the court. It allowed the court to still publicly promulgate the death sentence, maintaining its usefulness both as a show of authority and perhaps also as a deterrant, but without the risk of creating new sources of vendetta and hatred among the parties, leaving alive the possibility for a future peace between them. The legal system facilitated reconciliation between parties in precisely this way, by allowing a return from ban after a period of time if peace could be made with the offended party. As was previously discussed, the commune allowed the families and creditors of those banned for homicide to collect money that was owed to them, and in this way strategies could be enacted to protect the property of the accused; by using bans of contumacy, the city could hope to place distance between parties in conflict and allow for legal reconciliation after some time had passed. Confession and peacemaking allowed for this kind of reconciliation. And acquittal was far from unknown: rates of outright acquittal at trial, while lower than in the previous century at Perugia, were still generous when compared to acquittal rates of modern justice systems. Solutions to criminal trials were multifaceted and operated both before the judge and outside his court to bring resolution to criminal acts and to maintain order.

218 Chambers and Dean, Clean Hands and Rough Justice, 83. 